\title{
Transnational Markets for Sustainable Development Governance The Case of REDD+
}

\author{
Gallemore, Caleb; Jespersen, Kristjan
}

Document Version

Accepted author manuscript

Published in:

World Development

DOI:

10.1016/j.worlddev.2016.06.009

Publication date:

2016

License
CC BY-NC-ND

Citation for published version (APA):

Gallemore, C., \& Jespersen, K. (2016). Transnational Markets for Sustainable Development Governance: The Case of REDD+. World Development, 86, 79-94. https://doi.org/10.1016/j.worlddev.2016.06.009

Link to publication in CBS Research Portal

\section{General rights}

Copyright and moral rights for the publications made accessible in the public portal are retained by the authors and/or other copyright owners and it is a condition of accessing publications that users recognise and abide by the legal requirements associated with these rights.

Take down policy

If you believe that this document breaches copyright please contact us (research.lib@cbs.dk) providing details, and we will remove access to the work immediately and investigate your claim. 


\title{
Transnational Markets for Sustainable Development Governance: The Case of REDD+
}

\section{Caleb Gallemore and Kristjan Jespersen}

\author{
Journal article (Post print version)
}

Cite: Transnational Markets for Sustainable Development Governance : The Case of REDD+. / Gallemore, Caleb; Jespersen, Kristjan. In: World Development, Vol. 86, 10.2016, p. 79-94.

DOI: 10.1016/j.worlddev.2016.06.009

Uploaded to Research@CBS: September 2016

(C) 2016. This manuscript version is made available under the CC-BY-NC-ND 4.0 license

http://creativecommons.org/licenses/by-nc-nd/4.0/ 


\section{Transnational Markets for Sustainable Development Governance: The Case of REDD+}

Caleb Gallemore, International Affairs Program, Lafayette College, Corresponding Author

International Affairs Program

Lafayette College

215 Oeschle Center for Global Education

730 High Street

Easton, PA 18042

gallemoc@lafayette.edu

Kristjan Jespersen, Department of Intercultural Communication and Management, Copenhagen Business School

Transnational sustainable development efforts often follow a project-based approach, in which funding sources, whether donor agencies, foundations, or firms, sponsor specific development activities, generally undertaken by nongovernmental organizations (NGOs) or social enterprises (Jordan \& van Tuijl, 2000; Mbabazi et al., 2002; Hudson, 2001; Clark, 2001; Green, 2014; Österblom \& Folke, 2013). Here, we explore the potential of conceptualizing the relationship between sustainable development funders and project proponents analogously to the market for venture capital (Atakan, 2006; Sørensen, 2007). In other words, we study the transnational market for project-based sustainable development governance. ${ }^{1}$ In particular, we are interested in how this change of reference might shed light on "who gets what" (Roth, 2015) in sustainable development efforts, a reformulation of an enduring question about how donors, here understood as donor agencies, funds and foundations, and firms, choose which projects to support. These choices, we argue, are constrained by the transaction costs involved in searching out and working with potential partners. In the absence of formal institutional mechanisms to alleviate transaction costs, markets like this one cannot be assumed to be Pareto optimal (Simon, 1996: 32-33).

\footnotetext{
${ }^{1}$ For purposes of clarity, throughout this paper we refer to the method of using individual projects to promote sustainable development as project-based sustainable development governance and the system of transactions between donors and project proponents underlying this approach the transnational market for project-based sustainable development governance.
} 
Like venture capitalists, donors seek specific project characteristics, while project proponents, like entrepreneurs, hope for a combination of financial support, expertise, and management flexibility. However, unlike venture capital, several constraints limit the use of a price mechanism in allocating donor funding to particular projects. First, there is a strong ethical component to foreign aid, which can moderate the allocation of aid according to objective project characteristics (Büthe et al. 2012; Roth, 2008). Second, project and donor characteristics are not easily measured or compared, and measurement practices themselves actually can distort aid objectives (Holzapfel, 2016; Sjöstedt, 2013).

Venture capital and, we argue, development projects, are examples of matching markets (Gale \& Shapley, 1962; Roth, 1982; Roth, 2015). The study of matching markets is well advanced has been used to improve the design of systems as diverse as kidney transplant exchanges (Roth et al., 2004) and the matching of students to residencies (Niederle \& Roth, 2003; Roth, 2003). ${ }^{2}$ Studies in this area have found that matching markets can suffer from thinness, in which too few market participants are available, congestion, in which the number of participants overwhelms existing information processing approaches, and strategic behavior, which can result in hiding information that might improve overall outcomes (Roth, 2008). These problems are similar to concerns often raised about project-based approaches to sustainable development, which are often described as featuring high transaction costs, weak coordination or even overt competition, and limited impact (Fyvie \& Ager, 1999; Vandeninden \& Paul, 2012; Balboa, 2014; Barthel et al., 2014; Fuchs et al., 2015; Korhonen-Kurki et al., 2015).

Despite these parallels, to our knowledge the matching market framework has yet to be applied in the context of project-based development. Indeed, the literature on aid allocation in general is often focused on country-level flows (Fuchs et al., 2015; Dabla-Norris, 2015; Barthel et al., 2014), though a variety of phenomena in development governance might be understood more clearly at the micro-level,

\footnotetext{
2 Other examples include early grain spot markets (Cronon, 1991), kidney transplant exchanges (Roth et al., 2004), employment markets (Atakan, 2006; Kohima \& Pathak, 2009), academic admissions (Kohima \& Pathak, 2009) and marriages (Gale \& Shapley, 1962).
} 
as project-based transactions. Examples include public-private sustainable development partnerships (Pattberg et al., 2012), private aid (Büthe et al. 2012), the Clean Development Mechanism (Michaelowa \& Jotzo, 2005), transnational polycentric governance (Biermann, 2007; Ostrom, 2010; Abbott, 2011; Kim, 2013; Gallemore \& Munroe, 2013; Österblom \& Folke, 2013; Galaz et al., 2016; Galaz et al., 2012), and networks of transnational activists (Keck \& Sikkink, 1998; Hertel, 2006; von Bülow, 2010; Carpenter, 2007, 2011; Gallemore \& Munroe, 2013; Gallemore et al. 2015; Moeliono et al., 2014; Murdie, 2014a), and, in principle, a range of official development aid activities with on-theground partners. These processes aid our understanding of who gets what in development, but also, inasmuch as funding relationships can be enduring, they structure patterns of interaction and power relations more generally (Townsend et al., 2004; Harsh et al., 2010; Balboa, 2014).

While stable and Pareto-optimal outcomes exist for some matching markets under relatively reasonable theoretical assumptions (Gale and Shapley, 1962; Roth, 1982; Inderst, 2001), real-world matching markets remain subject to inefficient outcomes and considerable transaction costs (Roth, 2015). A variety of market design solutions have been developed and implemented to address these limitations (Roth, 1989; Abdulkadiroğlu et al., 2004; Roth, 2003; Roth, 2008; Roth, 2015), but such mechanisms are weakly developed or absent in transnational governance. While not explicitly normative this article builds a case that the matching market framework can be a productive lens for transnational development governance. Perhaps the applicability of some of the techniques for improving matching markets in other contexts to sustainable development could be assessed in future work.

We utilize data on donor agencies’, funds’, and firms’ sponsorship of Reducing Emissions from Deforestation and Forest Degradation (REDD+) pilot projects as an example matching market for sustainable development governance. While developed in the orbit of United Nations Framework Convention on Climate Change (UNFCCC) negotiations, REDD+, as of the time of our data collection, 
had largely been undertaken in the form of voluntary pilot projects, bilateral arrangements, or as part of broader development packages (Gallemore \& Munroe, 2013). While the inclusion of REDD+ in Article 5 of the Paris Agreement of the United Nations Framework Convention on Climate Change (UNFCCC) may provide incentives to scale up activities to jurisdictional or even national levels, pilot projects dominated on-the-ground REDD+ activity at the time of data collection.

Like many matching markets in development governance, REDD+ lacks formal institutions to facilitate exchanges, and we would expect transaction costs to have substantial effects on who gets what. Particularly, we would expect that donors would rely on a series of strategies, including brokerage, trust building, and spatial specialization to address transaction costs arising from the need to search out, monitor, and maintain communication with project proponents. We test these hypotheses using exponential random graph models (ERGMs) of a network formed by 91 donors’ (see Table 1) sponsorship of 195 avoided deforestation and REDD+ pilot projects begun in developing countries between 1989 and 2012. ${ }^{3}$

The following two sections outline our case that transaction costs are likely to structure donoragent relationships in transnational sustainable development governance. Following this theoretical discussion, we provide a brief overview of REDD+, along with a justification for choosing REDD+ as an appropriate case for this analysis. We then outline our data collection process and analysis methodology. Finally, we present our results and discuss potential implications of the empirical findings.

\section{Transaction costs in markets for governance}

\footnotetext{
3 Because donors' choices to sponsor a given project both on the menu of projects available and the activities of other donors, standard regression approaches, which require independence of observations, are not appropriate for our research. Designed to model network formation, in which observations are not independent, ERGMs provide an excellent approach for our analysis, which conceives of sponsorship as a network of transactions between donors and projects.
} 
We conceptualize the relationship between donors and sustainable development projects as a matching market in which donors transact with project proponents. In the absence of formal institutions that would facilitate information discovery and matching, we hypothesize, the evolving structure of the network of actors' exchanges will be heavily constrained by transaction costs, which narrow the scope of feasible partnerships. Originally conceived as the costs associated with using market prices to regulate exchanges (Coase, 1937), transaction costs are perhaps most succinctly defined by North (1990, p. 27) as "the costs of measuring the valuable attributes of what is being exchanged and the costs of protecting rights and policing and enforcing agreements.” Williamson $(1975,1979)$ enumerates further costly preconditions for long-term collaboration: common knowledge, common language, trust, and, in some cases, infrastructure are key examples. Interaction can be expensive.

For simplification and clarity, we can identify three primary sources of transaction costs in a transnational matching market for project-based sustainable development governance. First, search costs are necessarily high in matching markets due to the need to discover information about proposed projects and donor requirements. Finding interested funders may not be a trivial matter, especially for truly innovative projects.

Second, there are costs involved in negotiating, monitoring, and managing the principal-agent relationship between donors and project proponents (Pollack, 1997; Nielson \& Tierney, 2003). Project proponents' interests may not be fully aligned with donors' strategic objectives, placing proponents in the position of deciding either to compromise some objectives or engage in some resistance (Harsh et al., 2010). Cooperation can be impeded by a lack of trust (Murdie, 2014a; Doherty \& Doyle, 2014), differences in tactics (Lauterbach, 2007), varied institutional settings (von Bülow, 2010; Stroup, 2012; Doherty and Doyle, 2014), conflicts between organizations’ accountability to divergent principals (Andrews, 2014; Atack, 1999), and reputational concerns (Cooley \& Ron, 2002; Johnson \& Prakash, 2007; Hudson, 2001; Clark, 2001). 
Finally, there are ongoing costs involved in building and maintaining regular and effective communication required for successful engagement in common projects. As Williamson (1975, p. 22) puts it, “despite their best efforts, parties may find that language fails them (possibly because they do not possess the requisite vocabulary or the necessary vocabulary has not been devised).” North (2005), similarly, notes that language, culture, and practical, tacit knowledge can be difficult to transfer, and others note that transnational cooperation requires successful translation between institutional and cultural contexts (Mosse, 2005; Balboa, 2014; Pasgaard, 2015). We consider each of these costs, in turn, from the perspective of donors to and proponents of sustainable development projects.

\section{Donors}

Organizations interested in sponsoring sustainable development projects may face a large number of project proponents clamoring for support and limited time to make a decision. While it may not be necessary to seek out partnerships, as partners can reasonably be expected to come to them, funders of sustainable development governance are challenged by the need to seek the right partners and to sift through proposals to find those that most closely match programmatic objectives. Because many large institutional donors' funding activities are firmly tied to budgetary cycles, earmarks, political will, and organizational mission, there is a pressure to minimize search time (Goldman, 2005). If the number of possible projects is very large relative to the search time, then, donors may face some significant search constraints.

Donors' search for projects is further complicated by uncertainty about the reliability of information supplied by project proponents - not to mention the reliability of the proponents themselves. Donors of sustainable development projects face an asymmetric information principalagent problem in that the organizations they fund have relative autonomy and private information about 
their preferences, local conditions, and project success or failure (Cooley \& Ron, 2002; Rivera-Santos \& Rufin, 2011). Allocating funds to organizations that can be trusted to support the donor agency's mandate, as a result, requires not only searching for potential partners, but also assessing performance in the face of strong incentives for organizations to misrepresent their activities (Burger \& Owens, 2010; Ebrahim, 2002, 2003; Mosse, 2005; Pasgaard, 2015).

Given the costs involved in search and due diligence, coupled with the limitations of resources and time, funders of sustainable development projects may satisfice (Simon, 1956, 1996), taking the best acceptable projects, rather than expending the search and monitoring costs entailed in finding optimal projects. As we discuss below, a variety of techniques can be used to minimize the costs of search and monitoring, though they may not ensure optimal matches.

\section{Proponents}

Project proponents must find relevant programs in the portfolios of donor agencies, funds, and foundations, or else negotiate directly with firms or other potential supporters. As in the case of donors, the number of options available may be large relative to an organization's time and resources, and programs can be idiosyncratic, so finding appropriate matches is difficult. Proponents must consider not only available funding, but also due diligence requirements, monitoring and reporting standards, and any other attendant administrative costs attached to funds, in addition to the fit of the program with the organization’s brand and mission (Barakso, 2010; Johnson \& Prakash, 2007; Prakash \& Gugerty, 2010; Sell \& Prakash, 2004; Yanacopulos, 2005). Finding the right mix of thematic compatibility, financial sufficiency, and administrative capacity is not trivial, particularly if the organization is poorly resourced. 
When appropriate funding sources are found, proponents must negotiate their own side of the principal-agent problem and its attendant monitoring costs. Project proponents are often beholden to donors (Andrews, 2014; Banks et al., 2015; Bebbington, 2005; Bob, 2005, 2009; Boulding, 2012; Herzer and Nunnenkamp, 2013; Thaut et al., 2012), as acquiring grants and other support can be crucial to organizational activities. Yet they also must balance advocacy concerns with funding, trying to protect their "brand" and retain their legitimacy and distinctiveness (Barakso, 2010; Cooley \& Ron, 2002; Bebbington, 2005; Hendrix \& Wong, 2013; Rodrigues, 2004; Bob, 2005; Banks et al., 2015). They also must address non-donor principals’ concerns (Andrews, 2014; Atack, 1999; Harsh et al., 2010). These strategic considerations result in a potential conflict of interest: donors should be motivated to protect their investments in projects, while recipients may wish to maximize their freedom of maneuver (Mitchell, 2014, 2013; Rauh, 2010; Elbers \& Schulpen, 2010; Elbers \& Arts, 2011).

Communication costs are also critical for proponents. The central problem here is that agents of transnational sustainable development governance face what Wong (2012, p. 4) calls a "transnational dilemma: appealing to broad-based principles while acknowledging local differences.” Transnational actors must speak language intelligible to donors when seeking funding and a local dialect when implementing their vision. Because knowledge and advice has to be created with particular audiences and purposes in mind, policy generally has to be adapted or translated to particular contexts (Mosse, 2005; Tsing, 2005; Peck and Theodore, 2010; Balboa, 2014; Pasgaard, 2015). Yet working across spatial scales and governmental levels involves considerable transaction costs (Hadden, 2015; Gallemore et al., 2015): information costs generally will be higher if information is physically distant, and it may be necessary to acquire facility with highly technical language - often literally foreign (Adger et al., 2005).

Both donors and project proponents face significant constraints in their choice of organizational partners, and we would expect these strategic constraints and potential conflicts of interest to affect 
who gets what in matching markets for project-based sustainable development. In other words, we should be able to detect the collective signature of these transaction costs in the pattern of donors' pilot project selection. In the following section, we derive testable hypotheses regarding patterns of donor's choices that we would expect to result from the strategic considerations outlined above.

\section{Transaction Costs and Donor Choices}

Both formal and informal institutions can help build trust and mitigate transaction costs (North, 1990, 2005; Greif, 2006; Paavola, 2007), but development project markets, like the one studied here, generally lack formal institutional mechanisms for making matches. As a result, we expect the constraints imposed by transaction costs to affect patterns of project support (Leifeld \& Schneider, 2012; Gallemore et al., 2015). We expect these patterns to exhibit a tendency to minimize search, communication, and monitoring costs and establish long-term trust. Unfortunately, the strategies that will be most observable on the basis of the data available at present serve to mitigate all three costs, making it impossible to separate fully the empirical contributions of the three different types. However, we do think that some strategies may affect one type of transaction cost more than the others, which allows for some tentative assessments of their relative importance.

\section{Search}

As noted above, finding promising partners can be a significant challenge for both donors and project proponents. One way to lower the costs of search is to utilize brokerage. As defined by von Bülow (2010: 108), brokerage involves "bridging initiatives that link actors (individuals, organizations, or sectors) that are separated by geographical distance, lack of trust, or lack of resources, or simply because they are unaware of each others’ existence.” Brokers are individuals or organizations 
strategically placed to bridge relationships between two disconnected social networks. By virtue of wearing multiple hats, brokers may facilitate partnership (Burt, 2005, p. 15-19; Ernstson et al., 2010; Olsson et al., 2004; Hahn et al., 2006; Olsson et al., 2007).

From the donors' perspective, it may lower transaction costs to partner with a highly visible international brand (Barakso, 2010; Dauvergne \& Lister, 2013) that signals credibility, a strategy that can have particular purchase with private sector supporters (King, 2007). In the specific case of REDD+, the most straightforward approach can be to partner with an established transnational NGO (TNGO; von Bülow, 2010). Most large TNGOs will have familiarity with policy processes, allowing them to engage effectively with donor practices and build confidence (Glynn, 2008), positioning them to broker (Burt, 2005) relations between donors and other project proponents. TNGOs also tend to have higher resource endowments than grassroots or national organizations, potentially enabling them to overcome the high costs of engaging in brokerage (Hadden, 2015). These characteristics should place transnational NGOs in an excellent position to broker collaboration with donors for specific projects. Summarizing this argument, we propose hypothesis H1:

- H1: Donors will tend to sponsor projects featuring TNGO project proponents.

As the ecology of organizations engaged in REDD+ continues to diversify, however, TNGOs may not be the only organizations equipped to broker relationships between projects and donors. Other organizations, including research groups and consultants, might also be important. This leads us to propose a second hypothesis:

- H2: Donors will tend to sponsor projects featuring project proponents headquartered in the same country as the donor in question.

While from the donor's perspective these strategies most importantly mitigate search costs, it is important to note that they also can affect costs of communication and expertise, which could be internalized by the broker, as well as providing opportunities for brokers to build trust between parties. 


\section{Monitoring}

The development of trust between organizations can be an important factor in collaboration (Murdie, 2014a; Doherty \& Doyle, 2014), as it alleviates information asymmetries and mitigates principal-agent problems (Van Slyke, 2006), lowering costs of monitoring. This suggests mechanisms that produce trust should facilitate matches. Burt (2005) argues that a key way in which trust emerges is repeated social interaction. As a result of repeated collaboration on a series of projects, partners can reduce uncertainty about preferences. In other words, we would expect past experience with one or more of the proponents of a project to make a donor more interested in sponsorship, leading to hypothesis H3:

- H3: Donors will tend to support projects whose proponents are prior partners.

As with the brokerage strategy discussed in the previous sub-section, however, this strategy does not only reduce monitoring costs, but potentially search and communication costs, as well. Nevertheless, as the primary mechanism here is increased trust, we can expect that the primary impact of this approach is on the costs of monitoring. ${ }^{4}$

\section{Communication}

When project donors are expanding their portfolios into new geographical or thematic areas, relying on old partners may not be an option. In addition, as discussed above, considerable local and tacit expertise in local politics and organizational activities may simply not be easily transferrable. One possible response is to restrict operations to a specific geographical area. This would provide an

\footnotetext{
${ }^{4}$ While it would be ideal to test how project proponents' past performance might affect donor interest, the fact that most REDD+ projects are ongoing and that there are not clear metrics for success has meant this was not possible with the current data.
} 
opportunity for organizational staff to develop expertise and build ongoing relationships with relevant stakeholders. Based on this argument, we could expect spatial clustering in project involvement (H4):

- H4: Donors’ project portfolios will be spatially clustered.

Again, this strategy has implications for the other transaction costs. It can lower costs of search by limiting the number of organizations with which the donor would need to be familiar and by taking advantage of denser social networks for reputation monitoring. The primary advantage of spatial specialization from a transaction cost perspective, however, seems to be developing local expertise.

It should be noted that patterns resulting from these strategies might also result from historical legacies of particular donor agencies', firms', or foundations' past strategies or characteristics of the pilot projects themselves. We discuss our strategy for controlling for these potential confounding effects in our methods section. In the following section, we briefly describe REDD+, which provides the case from which data for our statistical tests of these hypotheses are collected.

\section{Reducing Emissions from Deforestation and Forest Degradation (REDD+)}

Beset by informational challenges and uncertainty about the future of the global climate regime, REDD+ provides an excellent case for studying the role of transaction costs in shaping matching markets for sustainable development governance. Through its relatively rapid evolution, REDD+ has remained "a mechanism to reduce global greenhouse gas emissions by compensating countries for avoiding deforestation and degradation,” (Center for International Forestry Research, 2009, p. 10). The principle is simple enough: deforestation is generally undertaken because it is economically advantageous in the short term (Bonnie \& Schwartzman, 2003). Therefore, the logic goes, compensating people for the opportunity cost of deforestation is one way of making forest clearance less attractive. In its approach, therefore, REDD+ applies a payment for ecosystem service (PES) 
model of environmental governance (Angelsen et al., 2009), coupled with more traditional integrated conservation and development projects (ICDPs; see Sunderlin \& Sills, 2012). REDD+ also could be seen as one of a family of results-based approaches to development aid, based on measurable outcomes for which donors may provide incremental payments for delivery (Klingebiel \& Janus, 2014), with an aim to shift the focus of development financing from inputs to outputs (O’Brien \& Kanbur, 2014; Kenny \& Savedoff, 2014). While intended to increase democratic accountability and recipient autonomy (Perakis \& Savedoff, 2015), Paul (2015: 316) suggests even results-based approaches “tend to reinforce accountability to donors and, in doing so, undermine mutual responsibility,” which leaves donors and project proponents facing the cooperation challenges discussed above.

Cooperation is difficult in REDD+ for a variety of reasons. Not only do organizations involved in REDD+ need to connect local land use practices and politics with detailed global standards, they also need to develop compelling narratives to secure the resources and expertise required to carry out their projects. Potential donors, on the other hand, may lack detailed local knowledge required to intervene in specific places to combat drivers of deforestation. Conflicts of interest often arise, as international actors frequently are interested in monitoring or profitability, while domestic actors may be concerned with autonomy and feasibility (McNeill, 2015; McGregor et al., 2015). The two sides may have common broad objectives and even need one another, but may often lack the information or institutional backing required to trust one another. Country-level studies of REDD+ policy networks support this interpretation, finding that transnational actors are often weakly connected to local civil society organizations (Brockhaus et al., 2014; Moeliono et al., 2014; Gallemore et al., 2014; Gallemore et al., 2015).

While the REDD+ moniker is relatively recent, the avoided deforestation model has been around for some time. Developed originally as a collaboration between conservationists, development NGOs, and utility firms, avoided deforestation project development slowed in the early 2000s as a 
result of the exclusion of such projects from the Clean Development Mechanism. Following the 2005 United Nations Framework Convention on Climate Change (UNFCCC) Conference of Parties in Montreal, avoided deforestation returned as Reducing Emissions from Deforestation (RED). Throughout the boom in interest in RED and REDD+ (and even REDD++; see ASB Partnership for the Tropical Forest Margins, 2009) that followed, coalitions of local and transnational NGOs, donor and recipient governments, international organizations, firms, funds, and foundations undertook a wide range of initiatives (Gallemore \& Munroe, 2013; den Besten et al., 2014).

Though “REDD+ has been a remarkably successful idea,” implementation requires complex legal and bureaucratic reforms in the face of entrenched status quo interests (Angelsen \& McNeil, 2012, p. 32). While the influential Stern and Eliasch Reviews (Stern, 2007; Eliasch, 2008) suggested REDD+ would be "big, quick, and cheap” (Angelsen \& McNeill, 2012, p. 33), the billions of dollars anticipated from mandatory carbon markets have failed to materialize. Instead of large-scale changes in forest policy, most REDD+ activities are being undertaken voluntarily, mostly in the form of "pilot projects." These are relatively small, intended to develop methods and models for future, larger activities. Ideally, jurisdictional or, as envisioned in the Cancun Agreement of the UNFCCC (Decision 1/CP.16, 2010: Par. 71), national measures would build on the project-based approach, scaling up successful techniques to the national scale. This approach was formally endorsed in Article 5 of the Paris Agreement of the UNFCCC (Draft decision -/CP.21, 2015), though progress toward national legislation - let alone implementation - has been slow (Brockhaus et al., 2015).

In the face of limited demand from carbon markets, Seymour and Angelsen (2012) suggest there has been an "aidification of REDD," as projects continue to rely on development funds and scaling up has been slow, such that REDD+ practices at the national scale compromise between international and domestic policy approaches (McGregor et al., 2015; Palmujoki \& Virtanen, 2016). As a result, REDD+ is being reshaped into a sustainable development initiative with an emphasis on 
forests (Angelsen \& McNeill, 2012), leading many project proponents to deemphasize the PES component of their efforts or to abandon the REDD+ label altogether (Sunderlin et al., 2014, 2015) and some commentators to dismiss the initiative as a fad (Fletcher et al. 2016). Given these funding constraints, donor agencies and large conservation NGOs remain particularly influential in forest conservation in many tropical forest countries (Di Gregorio et al., 2012), and at the time of data collection REDD+ remained a predominantly project-based approach.

REDD+ is an instructive example for several reasons. First, the bulk of REDD-related activities at the time represented by our data had taken place outside the formal UN system, usually in the form of collaboration between some combination of carbon offset firms, civil society organizations, development agencies, UN-system agencies, and national or subnational governments. Second, because the most explosive phase of REDD+'s development came after 2005, REDD+ projects have left an excellent trail of information online, in part due to the desire to "brand" projects for audiences in developed countries. Publication libraries, organizational and project websites, and other sources of digital information make it possible to develop a more extensive (albeit low resolution) picture of REDD+ activities than would be feasible for many other issue areas. Finally, because it targets a form of land use so integral to the lives of so many people, REDD+ is an interesting policy development in its own right.

\section{Methods}

A growing number of studies utilize network analysis (SNA; Wasserman and Faust, 1994) techniques to understand interorganizational collaboration (Carpenter, 2007, 2011; Kwak \& Lee, 2009; Wong, 2008; Lake \& Wong, 2009; Murdie \& Davis, 2011; Leifeld \& Schneider, 2012; Murdie, 2014b; Gallemore et al., 2014; Gallemore et al., 2015), though this work generally has not focused on the 
donor-agent relationship considered here. Modeling these transactions as a network, however, has an important methodological advantage. Choices in matching markets exhibit interdependencies (Chakraborty et al., 2010; Sørensen, 2007), in our case suggesting that donors and project proponents will adopt strategies on the basis of what other donors and project proponents are doing. Donors, for example, might attempt to divide efforts, such that no single project will receive more than one or two donors. Alternatively, because additional donors on a project to some extent hedges risk, donors might be more inclined to support projects that are supported by other donors. As project support will be related to donors' interests and resources, it also is possible that the more projects a donor supports, the more that donor may support in the future.

These example mechanisms demonstrate that we cannot assume that relationships between dyads of donors and projects are formed independently. In other words, Donor A's decision to support Project A may be affected by Donor B's choice to fund Project A, or even by Donor B's choice to support Project B. These processes pose a problem for regression approaches, which must assume observations are independent. While this means that regression approaches are not appropriate for testing our hypotheses, exponential random graph models (ERGMs) are an excellent alternative, providing a robust statistical framework for modeling network formation common in similar studies (Box-Steffensmeier and Christenson, 2014; Cranmer et al., 2014; Heaney, 2014; Thurner \& Binder, 2009; Leifeld \& Schneider, 2012). While closely related to logistic regression, these models are based on the idea that connections between nodes in a network are not formed independently and are therefore technically not regression models. To avoid the problematic assumption of independence, ERGMs model the network as a single observation and construct statistical significance tests based on comparison to a randomly generated sample of networks consisting of the same number of nodes.

A brief explanation of the network studied here is in order. From an SNA perspective, networks are composed of nodes (which can represent any entity) connected by links (which can represent any 
relationship). One distinguishing network feature is whether or not all nodes can in principle be related any other node. While many networks (often called one-mode) are defined as relations between the same types of nodes, affiliation (or two-mode) networks provide information on relations between a set of “actor” and “event” nodes, where actors can only be connected to events and vice-versa. Examples include individuals connected by sitting on the same corporate board, people connected by attending the same party, or governments connected by being members of a common intergovernmental organization (Wasserman \& Faust, 1994, ch. 8). The network modeled in this study is an affiliation network, with donors as actors, pilot projects as events, and edges coded when a donor is listed as a sponsor in project documentation.

This is by no means the first network-based study of REDD+ policy. Research undertaken as part of the Center for International Forestry Research (CIFOR)'s Global Comparative Study on REDD (GCS-REDD) has been premised on the idea that much of the policy action is to be found in messy, informal networks (Di Gregorio et al., 2012; Brockhaus et al., 2014). In a series of studies of media reports and actors involved in REDD+ in countries including Brazil (May et al., 2011; Gebara et al., 2014), Cameroon (Dkamela, 2011; Dkamela et al., 2014), Indonesia (Cronin \& Santoso, 2010; Indrarto et al., 2012), Mozambique (Sitoe et al., 2012), Nepal (Khatri et al., 2012; Bushley, 2014), Papua New Guinea (Babon et al., 2012; Babon et al., 2014), Tanzania (Rantala \& Di Gregorio, 2014), and Vietnam (Pham, 2011; Pham et al., 2012; Pham et al., 2014), research in the GCS-REDD provides considerable high-resolution information about REDD+ policy networks in the sites studied. This study has a different objective - to provide a low-resolution but global analysis of REDD+ policy development.

\section{Data Collection}

Gallemore and Munroe (2013) provide data on organizational collaboration on avoided deforestation and sustainable forest management pilot projects between 1989 and 2012 (see Figures 1 
and 2). In order to focus on REDD+ explicitly, only projects in developing countries were included in the analysis described here $(\mathrm{N}=195)$. These data, compiled from multiple datasets, as well as the authors' own searches, provide information on pilot projects' anticipated area, as well as an approximate geolocation of the project centroid. In addition, the data include a classification of the organizational type of all project partners, as well as the city where each organization's' headquarters is located.

Data collection procedures are described in detail in Gallemore and Munroe (2013), but, to summarize, lists of pilot projects were compiled from a variety of online sources, particularly the Center for International Forestry Research's Global Database of REDD+ and Other Forest Carbon Projects (Center for International Forestry Research, 2012), in addition to Cenamo et al. (2009), Ecosystem Marketplace (2012), Forest Carbon Asia (2012), Conservation International (2016), Verified Carbon Standard (2016), and Varming et al., (2010). Once names for all projects were collected, internet searches were conducted using Google to find project design documents, sponsoring organizations' web pages, and any press releases relating to the project. Organizations were listed as being involved in the project if they were mentioned as being involved in any documentation, were listed as authors of project design documents, or were listed as sponsors on project websites. Project locations were approximately geocoded based on maps in project design documents. Where maps were not available, projects were geocoded based on the nearest locatable feature discussed in project documentation (generally protected areas, settlements, or natural features).

Once organizations were identified, their websites were located if they existed. Based on the name and website of the organizations, organizations were coded as either government agencies, firms (private sector, for-profit organizations), NGOs (civil society, nonprofit organizations that engage in on-the-ground activities), funds or foundations (nonprofit organizations whose primary activities are the provision of grants), research organizations (universities and think-tanks), or international 
organizations (organizations created by but independent of national governments). Using the organization dataset, a new variable was coded for this analysis to classify developed country governments, foundations, international organizations, and firms whose primary business was not directly related to carbon markets as donors (see Table 1). We then performed searches of donors' websites to collect all countries in which a branch office was located.

The affiliation network formed by donors' sponsorship of REDD+ pilot projects is our dependent variable (see Figure 1). In data terms, we can imagine this as a matrix consisting of the same number of columns as there are projects $(\mathrm{N}=195)$ and the same number of rows as donors $(\mathrm{N}=91)$. Each cell in the matrix is either a 0, in which case the donor denoted by the row does not sponsor the project denoted by the column, or a 1 , in which case a sponsorship exists.

\section{Variables}

To test our hypotheses, we rely on a range of relational variables coded from the network data. First, to test for the effect of prior collaboration, a variable was constructed for each donor-project pair counting the number of prior collaborations between other organizations engaged in the project and the donor in question (Prior Collaboration). For the 3 projects for which starting years could not be found, the median starting year was assigned. A second set of relational variables capture characteristics of the organizations engaged in the project. For each project, the total number of transnational NGO project partners was computed (defined as an NGO headquartered outside the country where the project was sited; TNGOs). Third, we count the total number of organizations involved in the project, other than the donor in question, that are headquartered in the same country as the donor (Brokers). Finally, for each donor-project pair, a variable was coded that counted the number of projects within, first, 250, and, then, 500 kilometers where the donor was a project sponsor (Projects $250 \mathrm{KM}$; Projects $500 \mathrm{KM}$ ). 
Given that REDD+ is at some level a results-based approach, we would expect donor organizations to be attracted to project features that make them likely to yield a high return on investment. In other words, we would expect organizations to be attracted to projects that have both high potential for avoided emissions and, in the case of firms, high public relations value (McGregor et al., 2015). In particular, we would expect large projects in areas of high carbon density and at high risk of deforestation to be attractive in emission mitigation terms. This means there is a need to control for project size and carbon density to account for the available carbon pool, and the accessibility to markets, rate of deforestation, and rate of population change in the area to control for key deforestation drivers (Hosonuma et al., 2012; Rudel et al., 2009). In addition, there is interest on the part of donors, particularly firms, in supporting projects that have high public relations or corporate social responsibility value (Dixon \& Challies, 2015), so we additionally control for proximity to protected areas, which can demonstrate iconic protection.

To control for characteristics of pilot projects that might make them more attractive to interested organizations, leading to spurious results, buffers were used to approximate project areas and provide summary statistics of local conditions. For the purposes of analysis, the small percentage of projects for which data on project area were unavailable were assigned the median value of area across the dataset (ln Area $\mathrm{KM}^{2}$ ). A circular buffer was then generated around the project centroid, with the area of the buffer set to the area of the project. Mean values of control variables were then computed for the buffer. Because REDD+ is oriented toward emissions reductions, data on biomass carbon in the project area in 2000 were collected from the New IPCC Tier-1 Global Biomass Carbon Map (Ruesch and Gibbs, 2008; Carbon Density). Data on accessibility, measured by travel time in minutes to the nearest city of at least 50,000 people, was approximated by the cost-distance model reported in Uchida and Nelson (2010; Travel Time). Change in the local population density from 1990 to 2000 for an additional 25 kilometers beyond the project area, a potential indicator of pressure on forests, was 
estimated using the Gridded Population of the World, v. 3, dataset (Center for International Earth Science Information Network and Centro Internacional de Agricultura Tropical, 2005; Population Change). As an estimate of deforestation risk, the area of forest loss within 25 kilometers of the approximate project centroid was computed using the Global Forest Change 2000-2012 dataset (Hansen et al., 2013; Forest Loss). Finally, we compute the great circle distance, in kilometers, from the approximate project centroid to the nearest protected area in the same country listed in the World Database on Protected Areas (IUCN and UNEP-WCMC, 2016; Protected Area Distance).

In addition to these project characteristics, we also include controls indicating that the donor in question is a governmental agency or international organization (Public Organization), or is headquartered in the same country as the project (Same Country). We also include a variable counting the year in which a project was founded (Year). Finally, we include geometrically weighted degree (Geometrically Weighted Degree) terms for both donors and projects to control for additional unexplained variation in the degree distribution of both donors and projects. All variables are summarized in Table 2. 


\begin{tabular}{|c|c|c|}
\hline Abbott & Ford Fdn. & Nexen \\
\hline American Electric Power & Gazprom Marketing and & Oregon Climate Trust \\
\hline American Enterprise Systems & Trading & PacifiCorp \\
\hline African Development Bank & General Motors & Pearl Jam \\
\hline Air France & GFA Holding & People's Trust for Endangered \\
\hline Banco do Planeta & Good Planet & Species \\
\hline Bank BMI & Google & Petrobras \\
\hline Blue Moon Fund & Gordon and Betty Moore Fdn. & Plan Vivo \\
\hline Borneo Tropical Rainforest & Government of Australia & PriceWaterHouseCoopers \\
\hline Fdn. & Government of Belgium & Rainforest Fdn. \\
\hline British Petroleum & Government of Denmark & Red Sky \\
\hline Brother & Government of France & Rosenthal Fdn. \\
\hline Camco Global & Government of Germany & Red Sky \\
\hline Carbonfund.org & Government of Norway & Rosenthal Fdn. \\
\hline Cargill & Government of Spain & Shell \\
\hline Chinoin MX & Government of the Netherlands & Sky \\
\hline Critical Ecosystem Partnership & Government of the UK & TECMAN LTDA \\
\hline Fund & Government of the US & Tenaska Washington Partners II \\
\hline Chevron & Gulf Coast Bird Observatory & Toyota Motor Corporation \\
\hline Cifarma & HSBC & Tropicana \\
\hline Cinergy & Hyundai Motors America & Unilever \\
\hline Cirrus Group & Interamerican Development & United Nations \\
\hline Citigroup & Bank & Volaris Airlines \\
\hline Delft Hydraulics & Int'l Conservation Fund of & Walt Disney Company \\
\hline Dell & Canada & WE Energies \\
\hline Deloitte & International Resources Group & Wild Fdn. \\
\hline Delta Airlines & IXE Bank & Woodbury Fund \\
\hline Dian Fossey Gorilla Fund Int'l & Kanematsu Corporation & World Bank \\
\hline Dixie Chicks & KL Felicitas Fdn. & \\
\hline DLA Piper & Litner Fdn. & \\
\hline DTE Energy & Macarthur Foundation & \\
\hline Duke Energy & Marriott Int’l & \\
\hline Ecologic Development Fund & Mitsubishi Corp. & \\
\hline Eeg-Henriksen Anlegg & Nat'l Fish and Wildlife Fdn. & \\
\hline European Union & & \\
\hline Exelon Corp. & & \\
\hline Fiji Water & & \\
\hline
\end{tabular}

Table 1: Title: Donor organizations included in analysis $(\mathrm{N}=91)$. 


\begin{tabular}{|c|c|c|}
\hline Variable & Description & Explanation \\
\hline Dependent Variable & 1 if a donor is a project sponsor, 0 otherwise. & $\begin{array}{l}\text { Indicates which projects attract sponsorship from } \\
\text { which donors. }\end{array}$ \\
\hline Edges & $\begin{array}{l}\text { Baseline probability of a donor sponsoring a } \\
\text { project. }\end{array}$ & $\begin{array}{l}\text { Similar to an intercept term in a standard } \\
\text { regression. }\end{array}$ \\
\hline TNGOs & Count of transnational NGO project partners. & $\begin{array}{l}\text { Test the hypothesis that TNGOs will be more } \\
\text { effective in attracting donor support than other } \\
\text { organizations. }\end{array}$ \\
\hline Brokers & $\begin{array}{l}\text { Count of all project partners headquartered in } \\
\text { the same country as the donor. }\end{array}$ & $\begin{array}{l}\text { Test the hypothesis that organizations } \\
\text { headquartered in the same country as the donor } \\
\text { will be more likely to attract support. }\end{array}$ \\
\hline Prior Collaboration & $\begin{array}{l}\text { Total number of donor's prior collaborations } \\
\text { with project partners. }\end{array}$ & $\begin{array}{l}\text { Test the hypothesis that prior collaboration builds } \\
\text { trust and lowers transaction costs. }\end{array}$ \\
\hline Projects $250 \mathrm{KM}$ & $\begin{array}{l}\text { Number of projects within } 250 \text { kilometers of } \\
\text { which donor is a sponsor. }\end{array}$ & $\begin{array}{l}\text { Test the hypothesis that organizations will engage } \\
\text { in spatial specialization. }\end{array}$ \\
\hline Projects $500 \mathrm{KM}$ & $\begin{array}{l}\text { Number of projects within } 500 \text { kilometers of } \\
\text { which donor is a sponsor. }\end{array}$ & $\begin{array}{l}\text { Test the hypothesis that organizations will engage } \\
\text { in spatial specialization. }\end{array}$ \\
\hline $\ln$ Area $\left(\mathrm{KM}^{2}\right)$ & Project area (hectares). ${ }^{2}$ & $\begin{array}{l}\text { Control for carbon emissions avoided by the } \\
\text { project. }\end{array}$ \\
\hline Carbon Density & Biomass carbon density (in $\mathrm{tCO}_{2}$ ), $2000{ }^{1}$ & $\begin{array}{l}\text { Control for carbon emissions avoided by the } \\
\text { project. }\end{array}$ \\
\hline Travel Time & $\begin{array}{l}\text { Mean travel ti me (i n mi nut es) to } \\
\text { a city of } \geq 50,000 .{ }^{1}\end{array}$ & $\begin{array}{l}\text { Control for carbon emissions avoided by the } \\
\text { project. }\end{array}$ \\
\hline Population Change & Population density change, $1990-2000{ }^{1}$ & $\begin{array}{l}\text { Control for carbon emissions avoided by the } \\
\text { project. }\end{array}$ \\
\hline Forest Loss & $\begin{array}{l}\text { Forest loss within } 25 \text { kilometers of project } \\
\text { centroid, 2000-2012. }{ }^{1}\end{array}$ & $\begin{array}{l}\text { Control for carbon emissions avoided by the } \\
\text { project. }\end{array}$ \\
\hline $\begin{array}{l}\text { Protected Area } \\
\text { Distance }\end{array}$ & $\begin{array}{l}\text { Great circle distance, in kilometers, to the } \\
\text { nearest protected area listed in the World } \\
\text { Database on Protected Areas. }\end{array}$ & $\begin{array}{l}\text { Control for corporate social responsibility/public } \\
\text { relations benefits of a project. }\end{array}$ \\
\hline Total Organizations & $\begin{array}{l}\text { Total non-donor organizations involved in a } \\
\text { project. }\end{array}$ & $\begin{array}{l}\text { Control for total number of organizations, other } \\
\text { than donors, involved in a project. }\end{array}$ \\
\hline Public Organization & $\begin{array}{l}\text { Donor is a government agency or } \\
\text { international organization. }\end{array}$ & $\begin{array}{l}\text { Control for differing levels of resources and } \\
\text { interest between public and private organizations. }\end{array}$ \\
\hline Branch Office & Donor has a branch or headquarters office in & Control for spatial specialization resulting from \\
\hline
\end{tabular}




\begin{tabular}{|l|l|l|}
\hline & the project country. & historical legacy. \\
\hline Same Country & $\begin{array}{l}\text { Donor is headquartered in the same country as } \\
\text { the project. }\end{array}$ & Control for local sources of support. \\
\hline Year & Year in which the project was started. & Control for time trends. \\
\hline $\begin{array}{l}\text { Geometrically } \\
\text { Weighted Degree } \\
\text { (Donors) }\end{array}$ & $\begin{array}{l}\text { Geometrically weighted degree distribution } \\
\text { for donors. }\end{array}$ & $\begin{array}{l}\text { Control for other unobserved sources of } \\
\text { exceptional donor activity levels. }\end{array}$ \\
\hline $\begin{array}{l}\text { Geometrically } \\
\text { Weighted Degree } \\
\text { (Projects) }\end{array}$ & $\begin{array}{l}\text { Geometrically weighted degree distribution } \\
\text { for projects. }\end{array}$ & $\begin{array}{l}\text { Control for other unobserved sources of } \\
\text { exceptional project popularity. }\end{array}$ \\
\hline
\end{tabular}

Table 2: Title: Variables used in ERGM estimation. Description: 1 = variable converted to standard deviations for modeling; 2 = variable logged for modeling.

\section{Overview of ERGMs}

Because network edges cannot be assumed to have formed independently, logistic regression, which assumes independence of observations, is generally not applicable to network data (Cranmer \& Desmarais, 2011). ERGMs avoid this problem by taking the observed network as a single observation from a distribution of all possible networks consisting of the same number of nodes (Robins et al., 2007). They are designed to model local social processes generating the observed network by testing for a greater than random presence of network structures that would result from those processes (Robins et al., 2007, p. 179).

Because ERGMs take the network as a single observation, ERGM terms have a somewhat novel logic. Terms in ERGMs are based on network statistics, which measure structural properties of the observed network and are compared to the distribution of networks with the same number of nodes. Estimated coefficients in an ERGM are more readily intelligible in a specification of the model suggested by Hunter et al. (2008) based on change statistics - the change in the conditional log-odds of observing a given edge in the network as a result of changes in network statistics that result from 
adding the edge to the network, while holding constant all other edges. Positive coefficients indicate that the probability of observing any given edge increases with the amount that edge's presence increases the value of the corresponding network statistic (Goodreau et al., 2008; Cranmer \& Desmarais, 2011).

ERGMs are ideally estimated by maximum likelihood (MLE; Robins et al., 2007), but MLE is often intractable even at relatively small network sizes. This has led proponents of ERGMs to adopt Markov-Chain Monte Carlo (MCMC) MLE, which produces a simulated distribution of networks from a set of parameter values that are iteratively adjusted by comparing the distribution to the observed network and generating new parameters until the log-likelihood of the model is maximized (Robins et al., 2007).

There are several ways of testing the goodness of fit for ERGMs, but one of the most straightforward is to use the model to simulate a distribution of random networks and compare various measures of the observed network to the distribution of these measures in the simulated networks. Here we use two measures commonly applied to affiliation networks. The first is the degree distribution - the number of nodes with specific numbers of connections across the network. The second is the minimum geodesic distance, which measures the number of pairs of nodes separated from each other by different numbers of steps across the network. A good model should produce distributions of networks whose mean values for these measures differ from the observed values with a relatively low probability (that is, the p-value for difference of the observed values from the mean should be high; Robins et al., 2007).

\section{Limitations}

Because of the information collection approach, which relied heavily on information available via project design documents, online databases, and websites, the data utilized here are necessarily 
noisy, particularly in coding the spatial locations of projects. While many of the variables collected should be considered approximate only, the global scale and low resolution of the analysis helps to hedge against the effects of random data collection error. A further challenge comes from the fact that the data encompass a relatively lengthy period during which avoided deforestation efforts evolved considerably. Both more exacting data collection and comparison with other cases are warranted to provide more rigorous tests of the hypotheses proposed here.

\section{Results and discussion}

Visualizations of the network studied are presented in Figures 1 and 2, while model estimations are presented in Table 3. We estimate two models, one for each of our two spatial clustering buffer distances. Comparing the models on Bayesian Information Criteria (BIC), the model using a 500 kilometer buffer is a slightly better fit, but it also results in significant decline in the ability of the model to reproduce characteristics of the original network, presented in the goodness of fit results in Table 4. For this reason, the model with a 250 kilometer buffer appears to be a slightly better fit to the data. Fortunately, the substantive interpretation of the other variables in the model does not hinge on this choice, as the estimated coefficients in both models are quite similar. Across both models, we do find evidence of three of the four strategies discussed in our hypotheses above. To simplify and clarify our discussion here, we consider our hypotheses in relation to the three forms of transaction costs introduced above before discussing results for our control variables. 


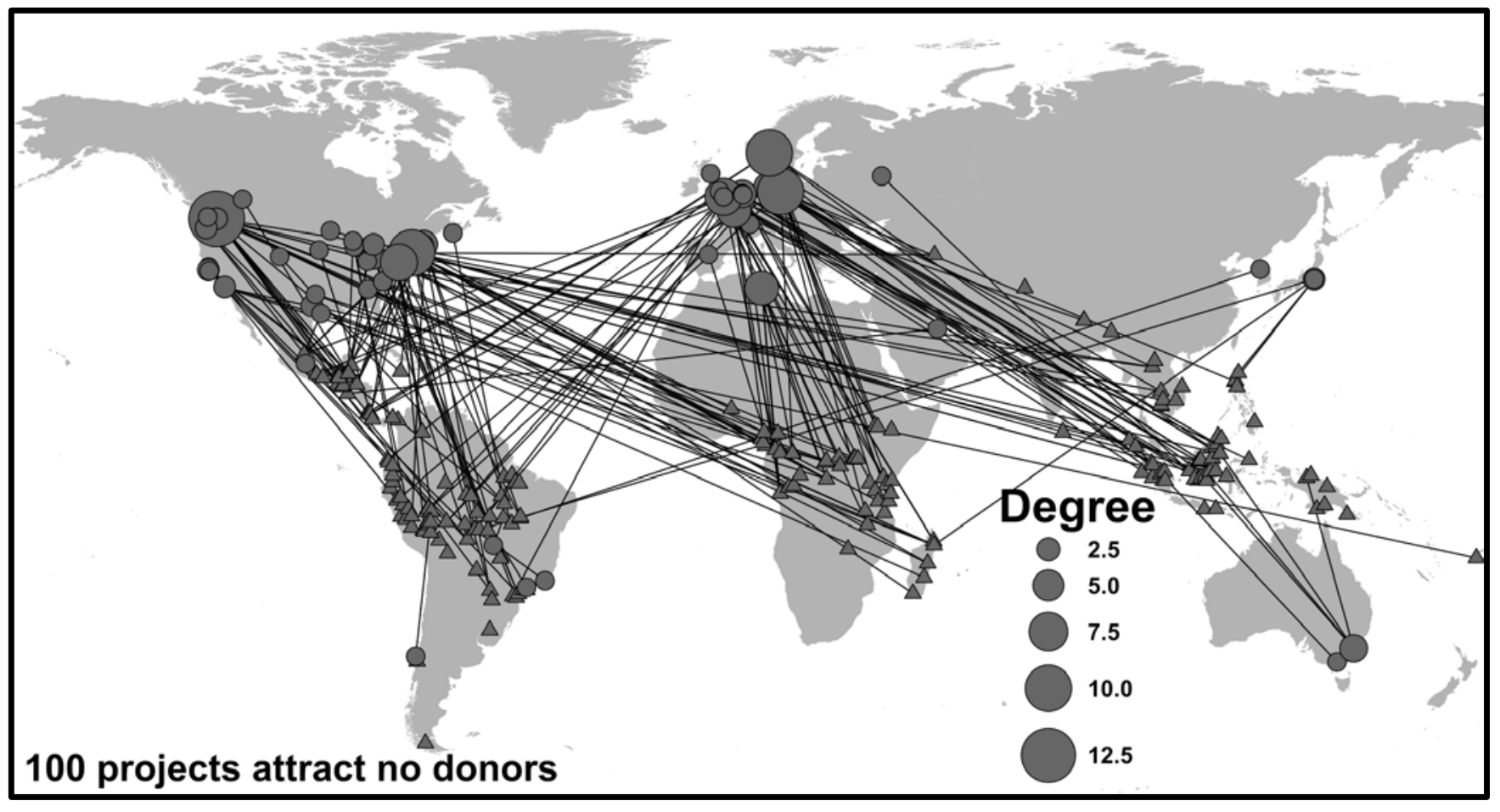

Figure 1: Title: REDD+ pilot projects $(\mathrm{N}=195)$ used in ERGM estimation. Description: Lines show sponsorship connections from donors (circles) to projects (triangles). Projection: WGS 84. Project data adapted from Gallemore and Munroe (2013). Plotted with ggplot2 (Wickham, 2009) in R 3.2.3 (R Core Team, 2015) and edited with Inkscape (Inkscape Board, 2015). 


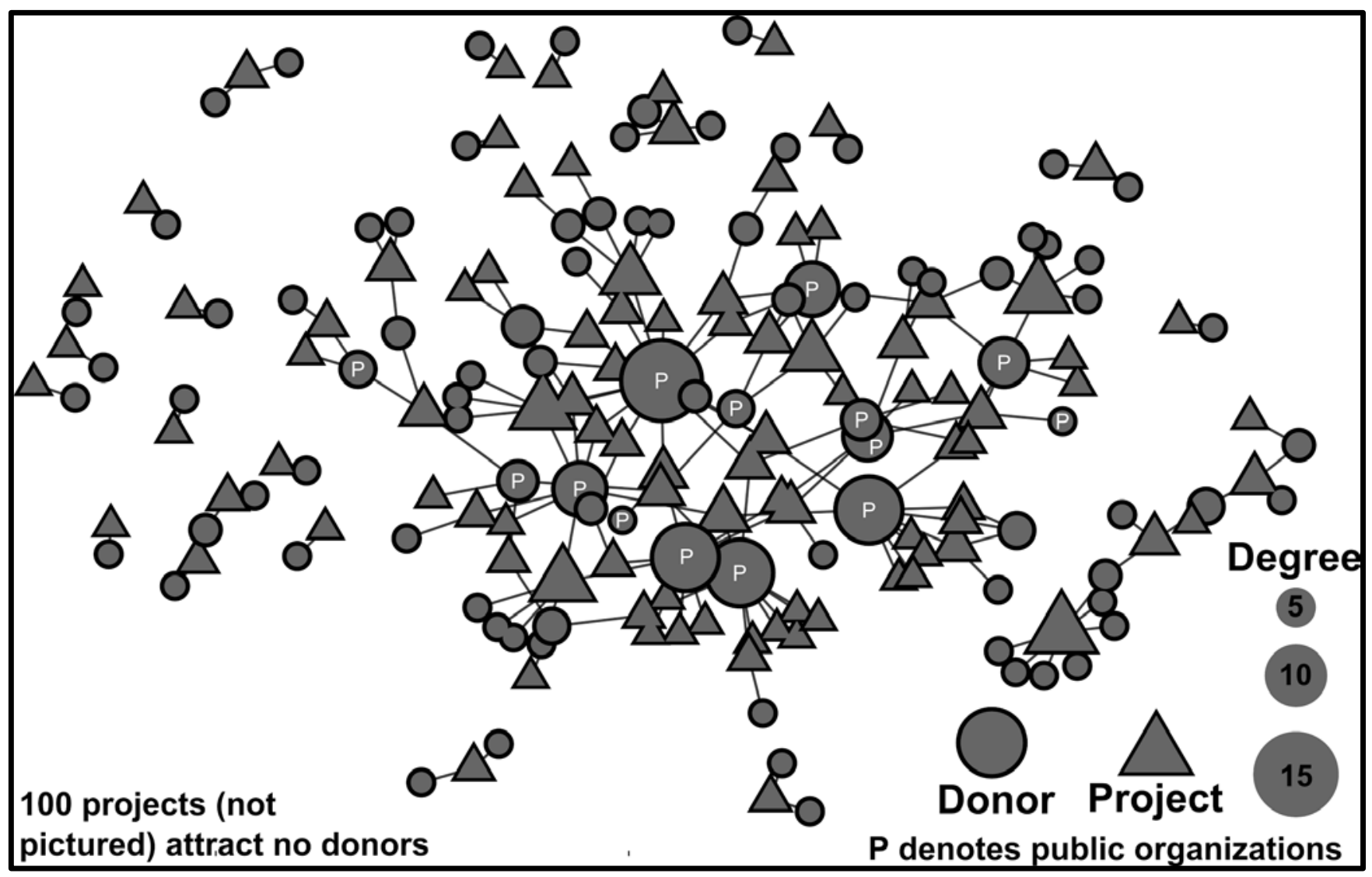

Figure 2: Title: REDD+ pilot projects $(\mathrm{N}=95)$ used in ERGM estimation with at least one donor connection. Description: Lines show sponsorship connections from donors to projects. Projection: Fruchterman-Reingold (1991). Project data adapted from Gallemore and Munroe (2013). Plotted with ggplot2 (Wickham, 2009) in R 3.2.3 (R Core Team, 2015) and edited with Inkscape (Inkscape Board, 2015). 
Dependent Variable: Donor Sponsorship

\begin{tabular}{|c|c|c|}
\hline & Model 1 & Model 2 \\
\hline Edges & $\begin{array}{c}-8.013^{* * *} \\
(0.843)\end{array}$ & $\begin{array}{c}-8.051^{* * *} \\
(0.845)\end{array}$ \\
\hline TNGOs & $\begin{array}{c}0.005 \\
(0.088)\end{array}$ & $\begin{array}{l}-0.0005 \\
(0.087)\end{array}$ \\
\hline Brokers & $\begin{array}{c}0.317 * * * \\
(0.039)\end{array}$ & $\begin{array}{c}0.306^{* * *} \\
(0.039)\end{array}$ \\
\hline Prior Collaboration & $\begin{array}{c}0.118^{* * * *} \\
(0.050)\end{array}$ & $\begin{array}{c}0.107^{* * *} \\
(0.051)\end{array}$ \\
\hline Projects $250 \mathrm{KM}$ & $\begin{array}{c}0.705^{* * * *} \\
(0.234)\end{array}$ & \\
\hline Projects $500 \mathrm{KM}$ & & $\begin{array}{c}0.524^{* * *} \\
(0.125)\end{array}$ \\
\hline ln Area $\left(\mathrm{KM}^{2}\right)$ & $\begin{array}{c}0.007 \\
(0.039)\end{array}$ & $\begin{array}{c}0.012 \\
(0.039)\end{array}$ \\
\hline Carbon Density & $\begin{array}{c}0.245^{* *} \\
(0.098)\end{array}$ & $\begin{array}{l}0.239 * * \\
(0.099)\end{array}$ \\
\hline Travel Time & $\begin{array}{l}-0.219^{*} \\
(0.113)\end{array}$ & $\begin{array}{l}-0.229 * \\
(0.112)\end{array}$ \\
\hline Population Change & $\begin{array}{c}-0.025 \\
(0.105)\end{array}$ & $\begin{array}{l}-0.025 \\
(0.104)\end{array}$ \\
\hline Forest Loss & $\begin{array}{l}-0.050 \\
(0.090)\end{array}$ & $\begin{array}{l}-0.053 \\
(0.091)\end{array}$ \\
\hline Protected Area Distance & $\begin{array}{l}-0.038 \\
(0.050)\end{array}$ & $\begin{array}{c}-0.040 \\
(0.050)\end{array}$ \\
\hline Total Organizations & $\begin{array}{c}0.074 * * * \\
(0.026)\end{array}$ & $\begin{array}{c}0.076^{* * *} \\
(0.026)\end{array}$ \\
\hline Public Organization & $\begin{array}{c}4.019 * * * \\
(0.587)\end{array}$ & $\begin{array}{c}3.961^{* * * *} \\
(0.589)\end{array}$ \\
\hline Branch Office & $\begin{array}{c}0.797 * * * \\
(0.200)\end{array}$ & $\begin{array}{c}0.749 * * * \\
(0.202)\end{array}$ \\
\hline Same Country & $\begin{array}{c}0.596 \\
(0.688)\end{array}$ & $\begin{array}{c}0.670 \\
(0.666)\end{array}$ \\
\hline Year & $-0.040 * * *$ & $-0.040 * * *$ \\
\hline
\end{tabular}




\begin{tabular}{lcc} 
Geometrically Weighted & $4.27 * * *$ & $4.28^{* * *}$ \\
Degree (Donors) & $(0.896)$ & $(0.899)$ \\
Geometrically Weighted & -0.363 & -0.362 \\
Degree (Projects) & $(0.394)$ & $(0.395)$ \\
\hline Akaike Inf. Crit. & 1748 & 1741 \\
Bayesian Inf. Crit. & 1888 & 1881 \\
$\mathrm{~N}$ & 17,745 & 17,745
\end{tabular}

Table 3: Title: Exponential random graph model estimations. Description: Variable effects on the probability that a donor sponsors a given project. $*=p<0.05 ; * *=p<0.01 ; * * *=p<0.001$. Estimated using ergm package (Hunter et al., 2008) in R 3.2.3 (R Core Team, 2015).

Model 1 Value (Obs.; Mean; $p$ )

\begin{tabular}{l|l}
\multicolumn{2}{c}{ Value (Obs.; Mean; } \\
\hline Degree & $3(17 ; 9.11 ; 0.00)$ \\
Minimum & \\
Geodesic Distance & \\
&
\end{tabular}

Model 2 Value (Obs.; Mean; $p$ )

$3(17 ; 9.34 ; 0.00)$

$7(817 ; 1367.85 ; 0.04)$ 8 (455; 1006.88; 0.02) Infinite (33685; 30683.18; 0.04)

Table 4: Title: Goodness of fit measures for exponential random graph models. Description: Table displays only situations where simulated networks are statistically significantly different from the observed. In no models were simulated distributions of edgewise-shared partners statistically significantly different from the observed. Computed using ergm package (Hunter et al., 2008) in $\mathrm{R}$ 3.2.3 (R Core Team, 2015).

\section{Search}

We hypothesized that partnering with TNGOs (H1) and organizations headquartered in their own country (H2) would be an effective way for donors to mitigate search costs. However, we find mixed results for these hypotheses. There is no evidence in our models that the presence of TNGOs has an effect on donors' choice of projects to support, so long as the total number of non-donor project proponents is controlled. We do, however, find a statistically and substantively significant effect of the total number of project proponents in each project that are headquartered in the same country as the 
donor in question. Each additional project proponent headquartered in the same country as a donor affects the probability of the donor choosing to sponsor the project more strongly than a standard deviation increase in carbon density or travel time to a city of over 50,000 people. Interestingly, this suggests that the brand of TNGOs may not be as important in securing funding as is their proximity to sources of funds. It also highlights that TNGOs are not necessarily the only important brokers in the evolving ecology of organizations engaged in REDD+.

This finding is consistent with observations in the qualitative literature on NGO-funder relations (Harsh et al., 2010; Boulding, 2012; Townsend et al., 2004; Balboa, 2014) that note the importance of the "transnational dilemma" (Wong, 2012) in structuring NGO strategies. The finding here suggests that the qualitative findings of these studies - which suggest that the capacity to network transnationally can be an important determinant of NGOs’ capacity to develop and implement projects - hold true more broadly. In addition, the finding supports the concern of students of transnational networks with the importance of brokers and brokerage relationships in accessing resources and linking up diverse groups (von Bülow, 2010; Hadden, 2015).

\section{Monitoring}

As expected (H3), we find that prior collaboration leads to subsequent interest on the part of donors, consistent with improved trust. A quick note is in order here. While it might be thought that this could result from sunk costs, these repeated collaborations involve distinct pilot projects, often in different countries, usually while the other projects are ongoing. In other words, familiarity and trust, not sunk costs, are the most reasonable explanation for repeated partnerships. While the magnitude of the effect is lower than that for brokers, it should also be noted that the range is higher. In addition, the 
effects of brokerage and prior collaboration are additive: transnational brokers, by making contact with a donor organization, have an advantage in securing future partnerships.

Researchers studying transnational networks have observed that a relatively small number of organizations can emerge as hubs, garnering considerable influence on the evolution and activity of the network as a whole (Carpenter, 2007, 2011; Carpenter et al., 2014). Combined with the importance of transnational brokers, our finding here might suggest one mechanism by which specific organizations become hubs. Organizations that have an advantage in securing donor interest in their activities have, as a result, an advantage in engaging in future projects, which can lead to further connections. This rich-get-richer dynamic could be one source of preferential attachment (Barabási \& Albert, 1999) leading to the formation of hubs in transnational advocacy and governance networks.

\section{Communication}

As expected (H4), we find that donors' project portfolios are spatially clustered. Here, it is important to note that the smaller regional buffer (250 kilometers) results in superior predictive model fit, suggesting that donors specialize in relatively small regions. We find this result despite controlling both for donors' presence in the country in question and the degree distribution among donors. This finding is indicative of regional specialization among donors over and above what is explained by the location of donors' regional offices. This strategy, as noted above, provides opportunities for organizations to gain and utilize local expertise, often by hiring staff from the region in question. In addition, however, it should be noted that this strategy can also minimize monitoring and search costs and is perhaps a less ideal indicator of communication costs than the other measures are as indicators of the other two forms of costs. 
This finding is consistent with other observations that the distribution of aid at a subnational level is often neither uniform nor efficient (Jablonski, 2014; Briggs, 2012, 2014; Runfola \& Napier, 2015). While much of the research on this issue focuses on overtly political constraints affecting aid allocation, here we suggest that there may be boundedly rational reasons for donors to spatially specialize, in addition to the effects of political constraints on aid allocation. The challenge here, which these studies also raise, is that specialization may make it more difficult for aid agencies to respond quickly and effectively to shifting needs on the ground.

\section{Controls}

Not all control variables are statistically significant, but those that are have effects in the expected directions. As anticipated, increases in carbon density are positively associated and increases in travel time from a city of 50,000 people negatively associated with donor sponsorship of projects. This is consistent with the idea that donors would allocate funds based on carbon benefits, but it is important to note that the effects are substantively weaker than the effects of the transaction cost variables. A standard deviation increase in either of the variables has a lower impact on donors' propensity to sponsor a project than the addition of a single broker organization.

As expected, public organizations are much more likely to sponsor any project than private organizations, and organizations are more likely to sponsor projects located in a country in which they have a branch office. Based on the effect of the geometrically weighted degree term, it appears that a few donors are particularly active, engaged in multiple projects, even controlling for all the other variables (Hunter, 2007). Projects with more non-donor project proponents seem to get a boost in attracting donor interest, but the effect is much weaker than the effect of additional brokers. There appears to be no statistically significant unexplained variation in degree distribution for projects, based 
on the results for geometrically weighted degree (Hunter, 2007). Finally, there appears to be a very slight decline in donor interest over time, although this simply could be because more recent projects did not have sufficient time to attract donors as of the time data were collected.

\section{Conclusion and implications}

We have argued that transaction costs can pose significant barriers to efficient transnational matching markets for sustainable development governance, constraining the range of feasible matches for donors and project proponents. Faced with uncertainty and asymmetric information, both donors and proponents need to find ways to make productive matches in order to carry out development projects. However, both types of organizations face significant costs of search, monitoring, and communication that must be overcome if matches are to be made.

We find evidence that donors can and do utilize a range of strategies to mitigate these costs and these strategies affect who gets what in REDD+. We find that the presence of brokers - project proponents headquartered in the same country as the donor in question - has a substantial effect on project attractiveness, suggesting this may be an important means of mitigating search costs, though brokerage can also potentially help with monitoring and communication. We also find that donors tend to rely on prior partners when selecting new projects, a pattern we interpret as indicative of efforts to economize on monitoring costs, but also clearly lowering search and, over time, communication costs. Finally, we find that donors tend to support spatial clusters of projects, consistent with efforts to increase expertise and lower communicative barriers, but also with clear implications for search and monitoring.

These findings provide prima facie evidence of the utility of thinking of project-based development governance as a type of matching market, an approach that could potentially be extended 
to a range of other applications, including public-private sustainable development partnerships (Pattberg et al., 2012), private aid (Büthe et al. 2012), and the Clean Development Mechanism (Michaelowa \& Jotzo, 2005). Expanding the scope of these analyses can provide important comparative insights. The Clean Development Mechanism, for example, is similar to the REDD+ pilot projects studied here in many respects, but it contains formal institutions that lower search and monitoring costs. Comparison of the two systems could be a way to develop deeper understanding of the relative importance of the three forms of transaction costs discussed here. Other promising avenues of research include survey and experimental analysis, which could be used to test hypotheses about how funders from donor agencies, firms, and foundations assess potential partners' attributes and identify appropriate matches.

In addition to these empirical questions, thinking of project-based development governance as a matching market raises some normative questions. Particularly, while funders appear to have adopted mechanisms for lowering the transaction costs involved in making matches, this may not be the most efficient or equitable means of facilitating these partnerships. While there are advantages in transnational actors serving as brokers to match donors and projects, Balboa (2014) points out that resolving the transnational dilemma is not straightforward. Resources devoted to communicating and securing support in global arenas are not devoted to understanding and communicating local concerns. While brokers can support connections, there is no guarantee that they can fully bridge these disparate networks, and, as a result, they may "set themselves up for failure on the ground” (Balboa, 2014; Banks et al., 2015). As discussed in the introduction, many matching markets have benefitted from relatively simple and inexpensive institutional innovations (Roth, 2015). It is possible that analogous approaches might be appropriate for project-based development governance, as well. In order to identify such approaches, however, it is necessary first to assess the matching market model in other transnational development contexts. 


\section{References}

Abbott, K. W. (2011). The transnational regime complex for climate change. Environment and

Planning C, 30(4): 571-590.

Abdulkadiroğlu, A., Pathak, P. A., and Roth, A. E. (2004). The New York City high school match. American Economic Review, 95(2): 364-367.

Adger, W., Brown, K., and Tompkins, E. (2005). The political economy of cross-scale networks in resource co-management. Ecology and Society, 10(2):9.

Angelsen, A., Kanninen, M., Sills, E., Sunderlin, W. D., and Wertz-kanounnikoff, S., eds. (2009). Realising REDD+: national strategy and policy options. Bogor, Indonesia: Center for International Forestry Research.

Angelsen, A. and McNeill, D. (2012). The evolution of REDD+. In Analysing REDD+: challenges and choices. Angelsen, A., Brockhaus, M., Sunderlin, W. D., and Verchot, L., eds. Bogor, Indonesia: Center for International Forestry Research. Pp. 31-49.

Andrews, A. (2014). Downward accountability in unequal alliances: explaining NGO responses to Zapatista demands. World Development, 54: 99-113.

ASB Partnership for the Tropical Forest Margins (2009). Reducing emissions from all land uses: the case for a whole landscape approach. Nairobi: ASB Partnership for the Tropical Forest Margins. Atack, I. (1999). Four criteria of development NGO legitimacy. World Development, 27(5): 855-864. Atakan, A. E. (2006). Assortative matching with explicit search costs. Econometrica, 74(3): 667-680. Babon, A., McIntyre, D., and Sofe, R. (2012). REDD+ Politics in the media: A case study from Papua New Guinea. Bogor, Indonesia: Center for International Forestry Research. 
Babon, A., McIntyre, D., Gowae, G. Y., Gallemore, C., Carmenta, R. Di Gregorio, M., and Brockhaus, M. (2014). Advocacy coalitions, REDD+, and forest governance in Papua New Guinea: how likely is transformational change? Ecology and Society, 19(3): 16. Retrieved from:

http://www.ecologyandsociety.org/vol19/iss3/art16/.

Banks, N., Hulme, D., and Edwards, M. (2015). NGOs, states, and donors revisited: still too close for comfort? World Development, 66: 707-718.

Balboa, C. M. (2014). How successful transnational non-governmental organizations set themselves up for failure on the ground. World Development, 54: 273-287.

Barabási, A.-L., and Albert, R. (1999). Emergence of scaling in random networks. Science, 286(5439): 509-512.

Barakso, M. (2010). Brand identity and the tactical repertoires of advocacy organizations. In Advocacy organizations and collective action. A. Prakash and M. K. Gugerty, eds. New York: Cambridge University Press. Pp. 155-176.

Barthel, F., Neumayer, E., Nunnenkamp, P., and Selaya, P. (2014). Competition for export markets an the allocation of foreign aid: The role of spatial dependence among donor countries. World Development, 64: 350-365.

Bebbington, A. (2005). Donor-NGO relations and representation of livelihood in nongovernmental aid chains. World Development, 33(6):937-950.

den Besten, J., Arts, W. B., and VerKooijen, P. (2014). The evolution of REDD+: an analysis of discursive-institutional dynamics. Environmental Science and Policy, 35: 40-48.

Biermann, F. (2007). 'Earth system governance' as a crosscutting theme of global change research. Global Environmental Change, 17(3-4): 326-337.

Bob, C. (2005). The marketing of rebellion: Insurgents, media, and international activism. New York: Cambridge University Press. 
Bob, C., ed. (2009). The international struggle for new human rights. Philadelphia: University of Pennsylvania Press.

Bonnie, R. and Schwartzman, S. (2003). Tropical reforestation and deforestation and the Kyoto Protocol. Conservation Biology, 17(1):4-5.

Box-Steffensmeier, J. M. and Christenson, D. P. (2014). The evolution and formation of amicus curiae networks. Social Networks, 36:82-96.

Boulding, C. (2012). Dilemmas of information and accountability: foreign aid donors and development NGOs. In The credibility of trnasnational NGOs: when virtue is not enough. P. A. Gourevitch, D. A. Lake, and J. G. Stein, eds. New York: Cambridge University Press. Pp. 115-136.

Briggs, R. C. (2012). Electrifying the base? Aid and incumbent advantage in Ghana. Journal of Modern African Studies, 50(4): 603-624.

Briggs, R. C. (2014). Aiding and abetting: Project aid and ethnic politics in Kenya. World Development, 64: 194-205.

Brockhaus, M., Di Gregorio, M., and Carmenta, R. (2014). REDD+ policy networks: exploring actors and power structures in an emerging policy domain. Ecology and Society, 19(4): 29. Retrieved from: http://www.ecologyandsociety.org/vol19/iss4/art29/.

Brockhaus, M., Korhonen-Kurki, K., Sehring, J., and Di Gregorio, M. (2015). Policy progress with REDD+ and the promise of performance-based payments. Working Paper 196. Bogor, Indonesia: Center for International Forestry Research.

Brown, S., Swingland, I. R., Hanbury-Tenison, R., Prance, G. T., and Myers, N. (2002). Changes in the use and management of forests for abating carbon emissions: Issues and challenges under the Kyoto Protocol. Philosophical Transactions of the Royal Society of London A, 360:1593-1605. von Bülow, M. (2010). Building transnational networks: Civil society and the politics of trade in the Americas. New York: Cambridge University Press. 
Burger, R., and Owens, T. (2010). Promoting transparency in the NGO sector: Examining the availability and reliability of self-reported data. World Development, 38(9): 1263-1277.

Burt, R. S. (2005). Brokerage and closure: An introduction to social capital. Oxford University Press, New York.

Bushley, B. R. (2014). REDD+ policy making in Nepal: toward state-centric, polycentric, or marketoriented governance? Ecology and Society, 19(3): 34. Retrieved from:

http://www.ecologyandsociety.org/vol19/iss3/art34/.

Büthe, T., Major, S., and de Mello e Souza, A. (2012). The politics of private foreign aid: Humanitarian principles, economic development objectives, and organizational interests in NGO private aid allocation. International Organization, 66: 571-607.

Carpenter, R. C. (2007). Setting the advocacy agenda: Theorizing issue emergence and nonemergence in transnational advocacy networks. International Studies Quarterly, pages 99-120.

Carpenter, R. C. (2011). Vetting the advocacy agenda: Network centrality and the paradox of weapons norms. International Organization, 65(01):69-102.

Carpenter, C., Duygulu, S., Montgomery, A. H., and Rapp, A. (2014). Explaining the advocacy agenda: Insights from the human security network. International Organization, 68(1): 449-470.

Cenamo, M. C., Pavan, M. N., Campos, M. T., Barros, A. C., and Carvalho, F. (2009). Casebook of REDD projects in Latin America. Washington, DC: The Nature Conservancy.

Center for International Earth Science Information Network and Centro Internacional de Agricultura Tropical (2005). Gridded Population of the World, Version 3 (GPWv3). New York: Center for International Earth Science Information Network.

Center for International Forestry Research (2012). Global database of REDD+ and other forest carbon projects interactive map. Bogor, Indonesia: Center for International Forestry Research. Retrieved from: http://www.cifor.org/gcs/redd-map/ 
Center for International Forestry Research (2009). Simply REDD: CIFOR's guide to forests, climate change, and REDD. Bogor, Indonesia: Center for International Forestry Research.

Clark, A. M. (2001). Diplomacy of conscience: amnesty international and changing human rights norms. Princeton, NJ: Princeton University Press.

Coase, R. H. (1937). The nature of the firm. Economica, 4(16):386-405.

Conservation International (2016). Climate, community, and biodiversity alliance website. Arlington, VA: Conservation International. Retrieved from: http://www.climate-standards.org/.

Cooley, A. and Ron, J. (2002). The NGO scramble: Organizational insecurity and the political economy of transnational actions. International Security, 53(4):5-39.

Cranmer, S. J. and Desmarais, B. A. (2011). Inferential network analysis with exponential random graph models. Political Analysis, 19(1):66-86.

Cranmer, S. J., Heinrich, T., and Desmarais, B. A. (2014). Reciprocity and the structural determinants of the international sanctions network. Social Networks, 36:5-22.

Crona, B. L. and Bodin, O. (2010). Power asymmetries in small-scale fisheries: a barrier to governance transformability? Ecology and Society, 15(4): 32. Retrieved from: http://www.ecologyandsociety.org/vol15/iss4/art32/.

Cronon, W. (1991). Nature’s metropolis: Chicago and the Great West. New York: W. W. Norton. Cronin, T. and Santoso, L. (2010). REDD + politics in the media: A case study from Indonesia. Bogor, Indonesia: Center for International Forestry Research.

Dabla-Norris, E., Minoiu, C., and Zanna, L.-F. (2015). Business cycle fluctuations, large macroeconomic shocks, and development aid. World Development, 69: 44-61.

Dauvergne, P., and Lister, J. (2013). Eco-business: A big-brand takeover of sustainability. Cambridge, MA: MIT Press. 
Di Gregorio, M., Brockhaus, M., Cronin, T., and Muharrom, E. (2012). Politics and power in national redd+ policy processes. In Analysing REDD+: challenges and choices. Angelsen, A., Brockhaus, M., Sunderlin, W. D., and Verchot, L., eds. Bogor, Indonesia: Center for International Forestry Research. Pp. 69-90.

Dixon, R., and Challies, E. (2015). Making REDD+ pay: Shifting rationales and tactics of private finance and the governance of avoided deforestation in Indonesia. Asia Pacific Viewpoint, 56(1): 6-20. Dkamela, G. P. (2011). The context of REDD+ in Cameroon: Drivers, agents, and institutions. Bogor, Indonesia: Center for International Forestry Research.

Dkamela, G. P., Brockhaus, M., Djiegni, F. K., Schure, J., and Mvondo, S. A. (2014). Lessons for REDD+ from Cameroon's past forestry law reform: a political economy analysis. Ecology and Society, 19(3): 30. Retrieved from: http://www.ecologyandsociety.org/vol19/iss3/art30/.

Doherty, B., and Doyle, T. (2014). Environmentalism, resistance and solidarity: The politics of Friends of the Earth International. New York: Palgrave Macmillan.

Ebrahim, A., (2002). Information struggles: The role of information in the reproduction of NGO-funder relationships. Nonprofit and Voluntary Sector Quarterly, 31(1): 84-114.

Ebrahim, A. (2003). Accountability in practice: Mechanisms for NGOs. World Development, 31(5): 813-829.

Ecosystem Marketplace (2012). Forest carbon portal. Wasthington, DC: Ecosystem Marketplace. Retrieved from: http://www.forestcarbonportal.com/.

Elbers, W. and Arts, B. (2011). Keeping body and soul together: Southern NGOs’ strategic responses to donor constraints. International Review of Administrative Sciences, 77(4):713-732. 
Elbers, W. and Schulpen, L. (2010). Decision making in partnerships for development: Explaining the influence of local partners. Nonprofit and Voluntary Sector Quarterly, 40(5):795-812.

Eliasch, J. (2008). Climate Change: Financing Global Forests. Technical report, Office of Climate Change of the United Kingdom, London.

Ernstson, H., Barthel, S., and Andersson, E. (2010). Scale-crossing brokers and network governance of urban ecosystem services : the case of stockholm. Ecology and Society, 15(4): 28. Retrieved from: http://www.ecologyandsociety.org/vol15/iss4/art28/.

Fletcher, R., Dressler, W., Büscher, B., \& Anderson, Z. R. (2016). Questioning REDD+ and the future of market-based conservation. Conservation Biology, Accepted Article. doi: 10.1111/cobi.12680.

Forest Carbon Asia (2012). Forest carbon projects. Manilla, Philippines: Forest Carbon Asia. Retrieved from: http://www.forestcarbonasia.org/activities/forest-carbon-projects/

Fruchterman, T. M. J., and Reingold, E. M. (1991). Graph drawing by force-directed placement. Software - Practice and Experience, 21(11): 1129-1164.

Fuchs, A., Nunnenkamp, P., and Öhler, H. (2015). Why donors of foreign aid do not coordinate: The role of competition for export markets and political support. The World Economy, 38(2): 255-285.

Fyvie, C., and Ager, A. (1999). NGOs and innovation: Organizational characteristics and constraints in development assistance work in the Gambia. World Development, 27(8): 1383-1395.

Galaz, V., Crona, B., Österblom, H., Olsson, P. and Folke, C. (2012). Polycentric systems and interacting planetary boundaries - emerging governance of climate change-ocean acidification-marine biodiversity. Ecological Economics, 81: 21-32.

Galaz, V., Österblom, H., Bodin, Ö., and Crona, B. (2016). Global networks and global change-induced tipping points. International Environmental Agreements, 16(2): 189-221.

Gale, D., and Shapley, L. S. (1962). College admissions and the stability of marriage. American Mathematical Monthly. 69(1): 9-15. 
Gallemore, C., Di Gregorio, M., Moeliono, M., Brockhaus, M., and Prasti H., R. D. (2015). Transaction costs, power, and multi-level forest governance in Indonesia. Ecological Economics, 114: 168-179. Gallemore, C., and Munroe, D. K. (2013). Centralization in the global avoided deforestation collaboration network. Global Environmental Change, 23(5):1199-1210.

Gallemore, C., Prasti H., R. D., and Moeliono, M. (2014). Discursive barriers and cross-scale forest governance in Central Kalimantan, Indonesia. Ecology and Society, 19(2): 18. Retrieved from: http://www.ecologyandsociety.org/vol19/iss2/art18/.

Gebara, M. F., Fatorelli, L., May, P., and Zhang, S. (2014). REDD+ policy networks in Brazil: constraints and opportunities for successful policy making. Ecology and Society, 19(3): 53. Retrieved from: http://www.ecologyandsociety.org/vol19/iss3/art53/.

Glynn, M. A. (2008). Beyond constraint: How institutions enable identities. In The Sage handbook of organizational institutionalism. Greenwood, R., Oliver, C., Sahlin-Andersson, and Suddaby, R., eds. London: Sage. Pp. 413-430.

Goodreau, S. M., Handcock, M. S., Hunter, D. R., Butts, C. T., and Morris, M. (2008). A statnet Tutorial. Journal of Statistical Software, 24(9):1-27.

Goldman, M. (2005). Imperial nature: The World Bank and struggles for social justice in the age globalization. New Haven, CT: Yale University Press.

Green, J. F. (2014). Rethinking private authority: agents and entrepreneurs in global environmental governance. Princeton, NJ: Princeton University Press.

Greif, A. (2006). Institutions and the path to the modern economy: Lessons from medieval trade. Cambridge University Press, New York. 
Hadden, J. (2015). Networks in contention: The divisive politics of climate change. New York:

Cambridge University Press.

Hahn, T., Olsson, P., Folke, C., and Johansson, K. (2006). Trust-building, knowledge generation and organizational innovations: The role of a bridging organization for adaptive comanagement of a wetland landscape around Kristianstad, Sweden. Human Ecology, 34(4):573-592.

Hansen, M. C., Potapov, P. V., Moore, R., Hancher, M., Turubanova, S. A., Tyukavina, A., Thau, D., Stehman, S. V., Goetz, S. J., Loveland, T. R., Kommareddy, A., Egorov, A., Chini, L., Justice, C. O., and Townshend, J. R. G. (2013). High-resolution global maps of 21st-century forest cover change. Science, 342(6160):850-3.

Harsh, M., Mbatia, P., and Shrum, W. (2010). Accountability and inaction: NGOs and resource lodging in development. Development and Change, 41(2): 253-278.

Heaney, M. T. (2014). Multiplex networks and interest group influence reputation: An exponential random graph model. Social Networks, 36:66-81.

Hendrix, C. S. and Wong, W. H. (2013). Knowing your audience: How the structure of international relations and organizational choices affect Amnesty International's advocacy. The Review of International Organizations, 9(1):29-58.

Hertel, S. (2006). Unexpected power: Conflict and change among transnational activists. Ithaca, NY: Cornell University Press.

Herzer, D., and Nunnenkamp, P. (2013). Private donations, government grants, commercial activities, and fundraising: Cointegration and causality for NGOs in international development cooperation. World Development, 46: 234-251. 
Holzapfel, S. (2016). Boosting or hindering aid effectiveness? An assessment of systems for measuring donor agency results. Public Administration and Development, Early View. DOI: 10.1002/pad. Hosonuma, N., Herold, M., De Sy, V., de Fries, R. S., Brockhaus, M., Verchot, L., Angelsen, A., and Romijn, E. (2012). An assessment of deforestation and forest degradation drivers in developing countries. Environmental Research Letters, 7(4): 044009. Retrieved from: http://iopscience.iop.org/article/10.1088/1748-9326/7/4/044009 Hudson, A. (2001). NGOs' transnational advocacy networks: From 'legitimacy' to 'political responsibility’? Global Networks, 1(4):331-352.

Hunter, D. R. (2007). Curved exponential family models for social networks. Social Networks, 29(2): 216-230.

Hunter, D. R., Handcock, M. S., Butts, C. T., Goodreau, S. M., and Morris, M. (2008). ergm: A package to fit, simulate and diagnose exponential-family models for networks. Journal of Statistical Software, 24(3).

Inderst, R. (2001). Screening in a matching market. Review of Economic Studies, 68(4): 849-868. Indrarto, G. B., Murharjanti, P., Khatarina, J., Pulungan, I., Ivalerina, F., Rahman, J., Prana, M. N., Resosudarmo, I. A. P., and Muharrom, E. (2012). The context of REDD+ in Indonesia: Drivers, agents, and institutions. Bogor, Indonesia: Center for International Forestry Research IUCN and UNEP-WCMC (2016). The world database on protected areas (WDPA). February 2016. Cambridge, UK: UNEP-WCMC. Retrieved from: http://www.protectedplanet.net/terms. Jablonski, R. S. (2014). How aid targets votes: The impact of electoral incentives on foreign aid distribution. World Politics, 66(2): 293-330.

Jordan, L., and van Tuijl, P. (2000). Political responsibility in transnational NGO advocacy. World Development, 28(12): 2051-2065. 
Johnson, E. and Prakash, A. (2007). NGO research program: A collective action perspective. Policy Sciences, 40(3):221-240.

Keck, M. E. and Sikkink, K. (1998). Activists beyond borders: Advocacy networks in international politics. Ithaca, NY: Cornell University Press.

Kenny, C., and Savedoff, W. (2014). Results-based payments reduce the real costs of corruption in foreign aid. Washington, DC: Center for Glboal Development.

Khatri, D. B., Bhushal, R. P., Paudel, N. S., and Gurung, N. (2012). REDD+ politics in the media: A case study from Nepal. Bogor, Indonesia: Center for International Forestry Research.

Kim, D. (2013). International nongovernmental organizations and the global diffusion of national human rights institutions. International Organization, 67(3):505-539.

Kim, R. E. (2013). The emergent network structure of the multilateral environmental agreement system. Global Environmental Change, 23(5): 980-991.

King, A. (2007). Cooperation between corporation and environmental groups: A transaction cost perspective. Academy of Management Review, 32(3): 889-900.

Klingebiel, S., and Janus, H. (2014). Results-based aid: Potential and limits of an innovative modality in development cooperation. International Development Policy, 5(2). Retrieved from: http://poldev.revues.orgbcrfj.revues.org/1746.

Kohima, F., and Pathak, P. (2009). Incentives and stability in large two-sided matching markets. American Economic Review, 99(3): 608-627.

Korhonen-Kurki, K., Brockhaus, M., Bushley, B., Babon, A., Gebara, M. F., Kengoum, F., Pham, T. T., Rantala, S., Moeliono, M., Dwisatrio, B., and Maharani, C. (2015). Coordination and cross-sectoral integration in REDD+: Experiences from seven countries. Climate and Development, Online Early Access. Retrieved from: http://www.tandfonline.com/doi/full/10.1080/17565529.2015.1050979. 
Kwak, S.-Y. and Lee, Y. W. (2009). Using norms strategically: Transnational advocacy networks’ operation for North Korean human rights. Asian Perspective, 33(1):33-74.

Lake, D. A. and Wong, W. H. (2009). The politics of networks: Interests, power, and human rights norms. In Networked politics: Agency, power, and governance, M. Kahler, ed. Ithaca, NY: Cornell University Press. Pp. 127-150.

Lauterbach, C. (2007). The costs of cooperation: Civilian casualty counts in Iraq. International Studies Perspectives, 8(4):429-445.

Leifeld, P., and Schneider, V. (2012). Information exchange in policy networks. American Journal of Political Science, 56(3): 731-744.

May, P. H., Calixto, B., and Gebara, M. F. (2011). REDD+ Politics in the media: A case study from Brazil. Bogor, Indonesia: Center for International Forestry Research.

McGregor, A., Howson, P., Astuti, R., Dixon, R., Haalboom, B., Gavin, M., Tacconi, L., Afiff, S. (2015). Beyond carbon, more than forest? REDD+ governmentality in Indonesia. Environment and Planning A, 47(1): 138-155.

McNeill, D. (2015). Norway and REDD+ in Indonesia: The art of not governing? Forum for Development Studies, 42(1): 113-132.

Michaelowa, A., and Jotzo, F. (2005). Transaction costs, institutional rigidities and the size of the clean development mechanism. Energy Policy, 33(4): 511-523.

Mitchell, G. E. (2013). Collaborative propensities among transnational NGOs registered in the United States. American Review of Public Administration, 44(5): 575-599.

Mitchell, G. E. (2014). Strategic responses to resource dependence among transnational NGOs registered in the United States. VOLUNTAS: International Journal of Voluntary and Nonprofit Organizations, 25(1): 67-91. 
Moeliono, M., Gallemore, C., Santoso, L., Brockhaus, M., and Di Gregorio, M. (2014). Information networks and power: Confronting the 'wicked problem' of REDD+ in Indonesia. Ecology and Society, 19(2): 9. Retrieved from: http://www.ecologyandsociety.org/vol19/iss2/art9/.

Mosse, D. (2005). Cultivating development: An ethnography of aid policy and practice. Ann Arbor, MI: Pluto Press.

Murdie, A. (2014a). Scrambling for contact: The determinants of inter-NGO cooperation in nonWestern countries. The Review of International Organizations, 9(3): 309-331.

Murdie, A. (2014b). The ties that bind: A network analysis of human rights international nongovernmental organizations. British Journal of Political Science, 44(1): 1-27.

Murdie, A. and Davis, D. R. (2011). Looking in the mirror: Comparing INGO networks across issue areas. The Review of International Organizations, 7(2):177-202.

Niederle, M., and Roth, A. E. (2003). Unraveling reduces mobility in a labor market: Gastroenterology with and without at centralized match. Journal of Political Economy, 111(6): 1342-1352.

Nielson, D. L., and Tierney, M. J. (2003). Delegation to international organizations: Agency theory and World Bank environmental reform. International Organization, 57(2): 241-276.

North, D. C. (1990). Institutions, institutional change, and economic performance. New York: Cambridge University Press.

North, D. C. (2005). Understanding the process of economic change. Princeton, NJ: Princeton University Press.

O’Brien, T., and Kanbur, R. (2014). The operational dimensions of results-based financing. Public Administration and Development, 34(5): 345-358.

Olsson, P., Folke, C., Galaz, V., Hahn, T., and Schultz, L. (2007). Enhancing the fit through adaptive co-management: creating and maintaining bridging functions for matching scales in the Kristianstads 
Vattenrike Biosphere Reserve, Sweden. Ecology And Society, 12(1): 28. Retrieved from: http://www.ecologyandsociety.org/vol12/iss1/art28/.

Olsson, P., Folke, C., and Hahn, T. (2004). Social-ecological transformation for ecosystem management: the development of adaptive co-management of a wetland landscape in southern Sweden. Ecology And Society, 9(4): 2. Retrieved from: http://www.ecologyandsociety.org/vol9/iss4/art2/. Österblom, H., and Folke, C. (2013). Emergence of global adaptive governance for stewardship of regional marine resources. Ecology and Society, 18(2): 4. Retrieved from: http://www.ecologyandsociety.org/vol18/iss2/art4/.

Ostrom, E. (2010). Polycentric systems for coping with collective action and global environmental change. Global Environmental Change, 20(4): 550-557.

Paavola, J. (2007). Institutions and environmental governance: a reconceptualization. Ecological Economics, 1(15): 93-103.

Palmujoki, E., and Virtanen, P. (2016). Global, national, or market? Emerging REDD+ governance practices in Mozambique and Tanzania. Global Environmental Politics, 16(1): 59-78.

Pasgaard, Maya (2015). Lost in translation? How project actors shape REDD+ policy and outcomes in Cambodia. Asia Pacific Viewpoint, 56(1): 111-127.

Pattberg, P., Biermann, F., Chan, S., and Mert, A., eds. (2012). Public-private partnerships for sustainable development: Emergence, influence and legitimacy. Cheltenham, UK: Edward Elgar. Paul, E. (2015). Performance-based aid: Why it will probably not meet its promises. Development Policy Review, 33(3): 313-323.

Peck, J. and Theodore, N. (2010). Mobilizing policy: Models, methods, and mutations. Geoforum, 41(2):169-174. 
Perakis, R., and Savedoff, W. (2015). Does results-based aid change anything? Pecuniary interests, attention, accountability and discretion in four case studies. Policy Paper 052. Washington, DC: Center for Global Development.

Pham, T. T. (2011). REDD+ politics in the media: A case study from Vietnam. Bogor, Indonesia: Center for International Forestry Research.

Pham, T. T., Moeliono, M., Hien, N. T., Tho, N. H., and Hien, V. T. (2012). The context of REDD+ in Vietnam: Drivers, agents, and institutions. Bogor, Indonesia: Center for International Forestry Research.

Pham, T. T., Di Gregorio, M., Carmenta, R., Brockhaus, M., and Le, D. N. (2014). The REDD+ policy arena in Vietnam: participation and policy actors. Ecology and Society, 19(2): 22. Retrieved from: http://www.ecologyandsociety.org/vol19/iss2/art22/.

Pollack, M. A. (1997). Delegation, agency, and agenda setting in the European Community. International Organization, 51(1): 99-134.

Prakash, A., and Gugerty, M. K. (2010). Advocacy organizations and collective action: An introduction. In Advocacy organizations and collective action. A. Prakash and M. K. Gugerty, eds. New York: Cambridge University Press. Pp. 1-28.

R Core Team (2015). R: A language and environment for statistical computing. Vienna: R Foundation for Statistical Computing, Vienna. Retrieved from: https://www.R-project.org/.

Rantala, S., Di Gregorio, M. (2014). Multistakeholder environmental governance in action: REDD+ discourse coalitions in Tanzania. Ecology and Society, 19(2): 66. Retrieved from: http://www.ecologyandsociety.org/vol19/iss2/art66/.

Rauh, K. (2010). NGOs, foreign donors, and organizational processes: Pas sive NGO recipients or strategic actors? McGill Sociological Review, 1(1):29-45. 
Rivera-Santos, M. and Rufìn, C. (2011). Odd couples: Understanding the governance of firm-NGO alliances. Journal of Business Ethics, 94(S1): 55-70.

Robins, G. L., Pattison, P., Kalish, Y., and Lusher, D. (2007). An introduction to exponential random graph (p*) models for social networks. Social Networks, 29:173-191.

Rodrigues, M. G. M. (2004). Global environmentalism and local politics. New York: State University of New York Press.

Roth, A. E. (1982). The economics of matching: stability and incentives. Mathematics of Operations Research, 7(4): 617-628.

Roth, A. E. (1989). Two-sided matching with incomplete information about others’ preferences. Games and Economic Behavior, 1: 191-209.

Roth, A. E. (2003). The origins, history, and design of the resident match. Journal of the American Medical Association, 289(7): 364-367.

Roth, A. E. (2008). What have we learned from market design? The Economic Journal, 118: 285-310.

Roth, A. E. (2015). Who gets what - and why. New York: Houghton Mifflin Harcourt.

Roth, A. E., Sönmez, T., and Ünver, M. U. (2004). Kidney exchange. Quarterly Journal of Economics, 119(2): 457-488.

Rudel, T. K., Defries, R., Asner, G. P., and Laurance, W. F. (2009). Changing drivers of deforestation and new opportunities for conservation. Conservation Biology, 23(6): 1396-1405.

Ruesch, A. and Gibbs, H. K. (2008). New IPCC tier-1 global biomass carbon map for the year 2000. Carbon Dioxide Information Analysis Center, Oak Ridge National Laboratory, Oak Ridge, TN. Runfola, D. M., and Napier, A. (2015). Migration, climate, and international aid: Examining evidence of satellite, aid, and micro-census data. Migration and Development, Online Early Access. Sell, S. K. and Prakash, A. (2004). Using ideas strategically: The contest between business and NGO networks in intellectual property rights. International Studies Quarterly, pages 143-175. 
Seymour, F. and Angelsen, A. (2012). Summary and conclusions: REDD+ without regrets. In Analysing REDD: challenges and choices, A. Angelsen, M. Brockhaus, W. D. Sunderlin, and L. Verchot, eds. Bogor, Indonesia: Center for International Forestry Research. Pp. 318-334. Simon, H. A. (1956). Rational choice and the structure of the environment. Psychological Review, 63(2): 129-138.

Simon, H. A. (1996). The sciences of the artificial. 3rd ed. Cambridge, MA: MIT Press.

Sitoe, A., Salomao, A., and Wertz-Kanounnikoff, S. (2012). The context of REDD+ in Mozambique: Drivers, agents, and institutions. Bogor, Indonesia: Center for International Forestry Research. Sjöstedt, M. (2013). Aid effectiveness and the Paris Declaration: A mismatch between ownership and results-based management? Public Administration and Development, 33: 143-155.

Sørensen, M. (2007). How smart is smart money? A two-sided matching model of venture capital. Journal of Finance, 62(6): 2725-2762.

Stern, N. (2007). The economics of climate change: The Stern review. New York: Cambridge University Press.

Stroup, S. S. (2012). Borders among activists: International ngos in the United States, Britain, and France. Ithaca, NY: Cornell University Press.

Sunderlin, W. D., and Sills, E. O. (2012). REDD+ projects as a hybrid of old and new forest conservation approaches. In Analysing REDD+: challenges and choices. Angelsen, A., Brockhaus, M., Sunderlin, W. D., and Verchot, L., eds. Bogor, Indonesia: Center for International Forestry Research. Pp. 177-191.

Sunderlin, W. D., Ekaputri, A. D., Sills, E. O., Duchelle, A. E., Kweka, D., Diprose, R., Doggart, N., Ball, S., Lima, R., Enright, A., Torres, J., Hartanto, H., and Toniolo, A. (2014). The challenge of establishing REDD+ on the ground: Insights from 23 subnational initiatives in six countries. Bogor, Indonesia: Center for International Forestry Research. 
Sunderlin, W. D., Sills, E. O., Duchelle, A. E., Ekaputri, A. D., Kweka, D., Toniolo, A., Ball, S., Doggart, N., Pratama, C. D., Padilla, J. T., Enright, A., \& Otsyina, R. M. (2015). REDD+ at a critical juncture: Assessing the limits of polycentric governace for achieving climate change mitigation. International Forestry Review, Early Access. Retrieved from: http://www.cifor.org/library/5770/reddat-a-critical-juncture-assessing-the-limits-of-polycentric-governance-for-achieving-climate-changemitigation/.

Thaut, L., Stein, J. G., and Barnett, M. (2012). In defense of virtue: Credibility, legitimacy dilemmas, and the case of Islamic Relief. In The credibility of trnasnational NGOs: When virtue is not enough. P. A. Gourevitch, D. A. Lake, and J. G. Stein, eds. New York: Cambridge University Press. Pp. 137-164. Thurner, P. W. and Binder, M. (2009). European Union transgovernmental networks: the emergence of a new political space beyond the nation-state? European Journal of Political Research, 48(1):80-106. Townsend, J. G., Porter, G., and Mawdsley, E. (2004). Creating spaces of resistance: Development NGOs and their clients in Ghana, India and Mexico. Antipode, 36(5): 871-889.

Tsing, A. L. (2005). Friction: An ethnography of global connection. Princeton, NJ: Princeton University Press.

Uchida, H. and Nelson, A. (2010). Agglomeration index: Towards a new measure of urban concentration. In Urbanization and development: Multidisciplinary perspectives. J. Beall, B. GuhaKhasnobis, and R. Kanbur, eds. New York: Oxford University Press. Pp. 41-59.

United Nations Framework Convention on Climate Change (2010). Report of the Conference of the Parties on its sixteenth session, held in Cancun from 29 November to 10 December 2010. FCCC/CP/2010/7/Add. 1. Bonn, Germany: United Nations Framework Convention on Climate Change. Retrieved from: http://unfccc.int/resource/docs/2010/cop16/eng/07a01.pdf. 
United Nations Framework Convention on Climate Change (2015). Adoption of the Paris Agreement. FCCC/CP/2015/L.9. Bonn, Germany: United Nations Framework Convention on Climate Change. Retrieved from: https://unfccc.int/resource/docs/2015/cop21/eng/109.pdf.

Vandeninden, F., and Paul, E. (2012). Foreign aid transaction costs: What are they and when are they minimised? Development Policy Review, 30(3): 283-304.

Van Slyke, D. M. (2006). Agents or stewards: Using theory to understand the government-nonprofit social service contracting relationship. Journal of Public Administration Research and Theory, 17(2): 157-187.

Varming, M., Seeberg-Elverfeldt, C., and Tapio-Biström, M.-L. (2010). Agriculture, forestry and other land use mitigation project database. Rome, Italy: Food and Agriculture Organization. Retrieved from: http://www.fao.org/3/a-am010e.pdf.

Verified Carbon Standard (2016). VCS project database. Washington, DC: Verified Carbon Standard. Retrieved from: http://www.vcsprojectdatabase.org/.

Wasserman, S. and Faust, K. (1994). Social network analysis: Methods and applications. New York: Cambridge University Press.

Wickham, H. (2009). ggplot2: Elegant graphics for data analysis. New York: Springer.

Williamson, O. E. (1975). Markets and hierarchies: Analysis and antitrust implications. New York: The Free Press.

Williamson, O. E. (1979). Transaction-cost economics: The governance of contractual relations. Journal of Law and Economics, 22(2):233-261.

Wong, W. H. (2008). Centralizing principles : How Amnesty International shaped human rights politics through its transnational network. PhD thesis, University of California at San Diego. Wong, W. H. (2012). Internal affairs: How the structure of NGOs transforms human rights. Ithaca, NY: Cambridge University Press. 
Yanacopulos, H. (2005). The strategies that bind: NGO coalitions and their influence. Global Networks, 5(1): 93-110. 